\title{
Hybrid DC-DC Converter with Low Switching Loss, Low Primary Current and Wide Voltage Operation
}

\author{
Bor-Ren Lin ${ }^{*}+(\mathbb{D}$ and Yi-Kuan Lin
}

check for updates

Citation: Lin, B.-R.; Lin, Y.-K. Hybrid DC-DC Converter with Low

Switching Loss, Low Primary Current and Wide Voltage Operation. Energies 2021, 14, 2536. https://doi.org/ $10.3390 /$ en14092536

Academic Editor: Salvatore Musumeci

Received: 26 March 2021

Accepted: 27 April 2021

Published: 28 April 2021

Publisher's Note: MDPI stays neutral with regard to jurisdictional claims in published maps and institutional affiliations.

Copyright: (c) 2021 by the authors. Licensee MDPI, Basel, Switzerland. This article is an open access article distributed under the terms and conditions of the Creative Commons Attribution (CC BY) license (https:// creativecommons.org/licenses/by/ $4.0 /)$.
Department of Electrical Engineering, National Yunlin University of Science and Technology, Yunlin 640, Taiwan; m10812005@yuntech.edu.tw

* Correspondence: linbr@yuntech.edu.tw

+ Fellow, IET, Senior Member, IEEE.

\begin{abstract}
A full-bridge converter with an additional resonant circuit and variable secondary turns is presented and achieved to have soft-switching operation on active devices, wide voltage input operation and low freewheeling current loss. The resonant tank is linked to the lagging-leg of the full bridge pulse-width modulation converter to realize zero-voltage switching (ZVS) characteristic on the power switches. Therefore, the wide ZVS operation can be accomplished in the presented circuit over the whole input voltage range and output load. To overcome the wide voltage variation on renewable energy applications such as DC wind power and solar power conversion, two winding sets are used on the output-side of the proposed converter to obtain the different voltage gains. Therefore, the wide voltage input from 90 to $450 \mathrm{~V}\left(V_{\text {in,max }}=5 V_{\text {in,min }}\right)$ is implemented in the presented circuit. To further improve the freewheeling current loss issue in the conventional phase-shift pulse-width modulation converter, an auxiliary DC voltage generated from the resonant circuit is adopted to reduce this freewheeling current loss. Compared to the multi-stage DC converters with wide input voltage range operation, the proposed circuit has a low freewheeling current loss, low switching loss and a simple control algorithm. The studied circuit is tested and the experimental results are demonstrated to testify the performance of the resented circuit.
\end{abstract}

Keywords: phase-shift PWM converter; resonant converter; ZVS; circulating current

\section{Introduction}

For the elimination of the air pollution and emission of greenhouse gases, clean renewable energy sources with power electronic techniques have been investigated and developed for fuel cell [1,2], wind power [3,4], solar power [5,6] and battery storage system [7] applications. Solar power [8,9] is one of the most attractive clean energy sources. However, the problem of the solar panel output voltage is unstable. To solve this problem, DC-DC pulse-width modulation (PWM) converters with wide voltage variation capability were studied and researched. Full-bridge phase-shift pulse-width modulation (PSPWM) converter have been developed in [10] to have 4:1 (18 V-75 V) input voltage range operation. The synchronous rectifiers with the PSPWM scheme are adopted on the secondary side to control load voltage. The disadvantages of this circuit topology are a complicated control scheme and eight active switches. The other problems of this circuit topology are the output power and zero voltage switching (ZVS) range on active devices are related to the input voltage. In [11], the halfbridge PWM converter with multi-winding on the secondary side is proposed to control load voltage and have 2:1 ( $\left.V_{\text {in }}=250 \mathrm{~V}-400 \mathrm{~V}\right)$ voltage operation. Three active devices, four rectified diodes, four secondary windings and two filter inductors are adopted in this converter. The more component counts used in this converter will result in high cost and circuit reliability. In [12], a cascade DC-DC converter with PSPWM modulation is proposed to achieve wide input voltage operation $\left(V_{\text {in }}=600 \mathrm{~V}-800 \mathrm{~V}\right)$. However, the voltage range of this circuit topology is limited between $600 \mathrm{~V}-800 \mathrm{~V}$. The conventional three-level duty cycle control or frequency control converters can achieve the same voltage range operation. In [13], 
an asymmetric half-bridge resonant circuit with the buck-boost circuit and resonant circuit has been presented to have $2: 1\left(V_{\text {in }}=36 \mathrm{~V}-72 \mathrm{~V}\right)$ voltage operation. The main problem of this circuit topology is the unbiased voltage stresses on active switches for both primary and secondary sides. In [14], a hybrid converter with a half-bridge PWM circuit and boost circuit was presented to achieve about 2:1 ( $\left.V_{\text {in }}=45 \mathrm{~V}-75 \mathrm{~V}\right)$ input voltage operation. The basic structure of this circuit topology is a kind of series-connected converter. In [15], the resonant converter operated at the half bridge or full bridge resonant circuit has been studied to realize $V_{\text {in }}=80 \mathrm{~V}-200 \mathrm{~V}$ voltage operation. However, the resonant frequency at low and high input voltage ranges are different due to the different resonant capacitances on half-bridge and full-bridge resonant tanks. Therefore, the wide switching frequency range will happen in this circuit topology. In [16], the PSPWM converter with two isolation transformers has been developed to have 4:1 input voltage operation. This circuit has four different operating sub-circuits under different input voltage conditions. However, the control algorithm of this circuit topology is too complicated to be implemented. In [17], the input-parallel output-series converter has been studied to have wide voltage range capability. Eight active devices and eight rectifier diodes are needed to have a 4:1 voltage operation. This circuit topology uses more power semiconductors that will reduce the circuit reliability and increase the cost.

A hybrid soft-switching DC-DC PWM converter is presented to reduce switching losses on active devices, achieve low primary current at the freewheeling state and have 5:1 $\left(V_{\text {in }}=90 \mathrm{~V}-450 \mathrm{~V}\right)$ wide input voltage operation. The PSPWM modulation is used to control active devices and have zero voltage turn-on characteristic. The presented converter contains a resonant circuit and a full-bridge PWM circuit. The resonant circuit can extend the ZVS operation range and also reduce the primary freewheeling current. To extend the input voltage operation range, two secondary winding sets are used on the low voltage side. Thus, a 5:1 ( $\left.V_{\text {in }}=90 \mathrm{~V}-450 \mathrm{~V}\right)$ wide input voltage range can be realized in the studied hybrid circuit. Compared to the conventional PWM converters, the advantages of the presented converter are low switching loss, low primary freewheeling current, wide input voltage operation and a simple control scheme. The circuit diagram of the proposed PWM circuit is discussed in Section 2. The principles of operation are provided in Section 3. In Sections 4 and 5, the circuit characteristic and experiments of the prototype circuit are discussed and presented to show the circuit performance. In Section 6, the conclusions of the studied hybrid PWM circuit are presented.

\section{Circuit Diagram of the Proposed PWM Converter}

The conventional PSPWM converter and main PWM signals are given in Figure 1a. Six power semiconductors (four active devices and two rectifier diodes), two magnetic cores (one isolation transformer and one filter inductor) and one filter capacitor are normally used in this circuit topology to realize medium or high power applications. The disadvantages of the PSPWM converter are the hard switching operation of active devices on lagging leg and high freewheeling current. The serious switching loss on active devices will result in serious switching losses at high-frequency operation and a high freewheeling current will reduce circuit efficiency. To solve these two problems, a half-bridge inductor-inductor-capacitor $(L L C)$ converter can be added to a conventional full-bridge PSPWM converter as shown in Figure $1 \mathrm{~b}$ remark in purple. The circuit elements of $L L C$ converter include $S_{3}, S_{4}, L_{r}, C_{r}$, $T_{2}, D_{3}, D_{4}, C_{o, r}$ and $D_{r}$. The PSPWM converter and resonant circuit share the same active devices $S_{3}$ and $S_{4}$. Due to the ZVS operation characteristic of $L L C$ converter, active devices $S_{3}$ and $S_{4}$ can achieve ZVS turn-on operation with a wide load range. Therefore, the hard switching drawback is improved. Diode $D_{r}$ in Figure $1 \mathrm{~b}$ is used to connect two dc voltage terminals $V_{o, r}$ (output terminal of $L L C$ converter) and $V_{R}$ (the secondary rectified voltage). During power transfer interval $\left(\left|v_{a b}\right|>0\right), V_{R}>V_{o, r}$ and $D_{r}$ is reverse biased. However, $D_{r}$ will be forward biased at the freewheeling duration $v_{a b}=0$ under $S_{1}$ and $S_{3} \mathrm{ON}$ or $S_{2}$ and $\left.S_{4} \mathrm{ON}\right)$. Due to $D_{r}$ is conducting, the power flow at the freewheeling duration is from $V_{o, r}$ ( $L L C$ converter) to $V_{o}$ (load side) and the rectified voltage $V_{R}=V_{o, r}$. Under the freewheeling 
state, the primary leg voltage $v_{a b}=0$ and the secondary rectified voltage $V_{R}=V_{o, r}$. It can obtain the primary-side inductor voltage $v_{L P}=-n_{p 1} V_{o, r} / n_{s 1}<0$ and the primary current $i_{L P}$ will be declined to zero. Hence, the high circulating current drawback is overcome. In order to overcome and achieve wide voltage operation, four secondary windings are adopted in Figure $1 \mathrm{~b}$ remark in blue. For low voltage input conditions $\left(V_{i n, \min } \sim 2.2 V_{i n, \min }\right)$, $Q_{1}$ turns on and $Q_{2}$ turns off (Figure 2a). Thus, $D_{2}$ and $D_{3}$ are reverse biased. The proposed circuit has a high voltage gain with transformer turns ratio $N_{T 1}=n_{p 1} /\left(n_{s 1}+n_{s 2}\right)$. Under high voltage input case $\left(2.2 V_{i n, \min } \sim 5 V_{i n, \min }\right)$, the switches $Q_{1}$ turns off and $Q_{2}$ turns on (Figure $2 \mathrm{~b}$ ). Therefore, $D_{1}$ and $D_{4}$ are reverse biased and the present circuit has low voltage gain with transformer turns ratio $N_{T 1}=n_{p 1} / n_{s 2}$. Hence, the wide voltage operation, low freewheeling current and wide ZVS operation are realized in the presented hybrid PWM converter.
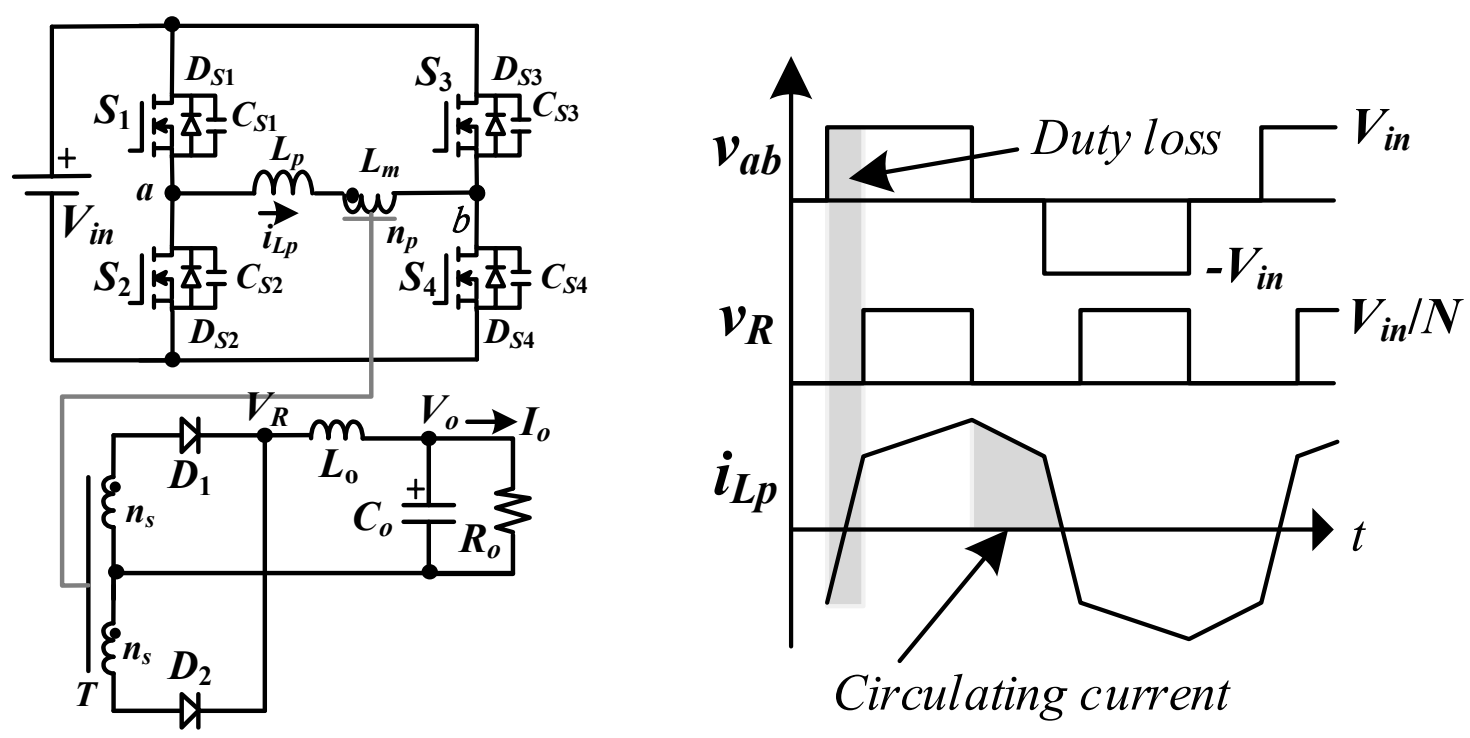

Circulating current

(a)
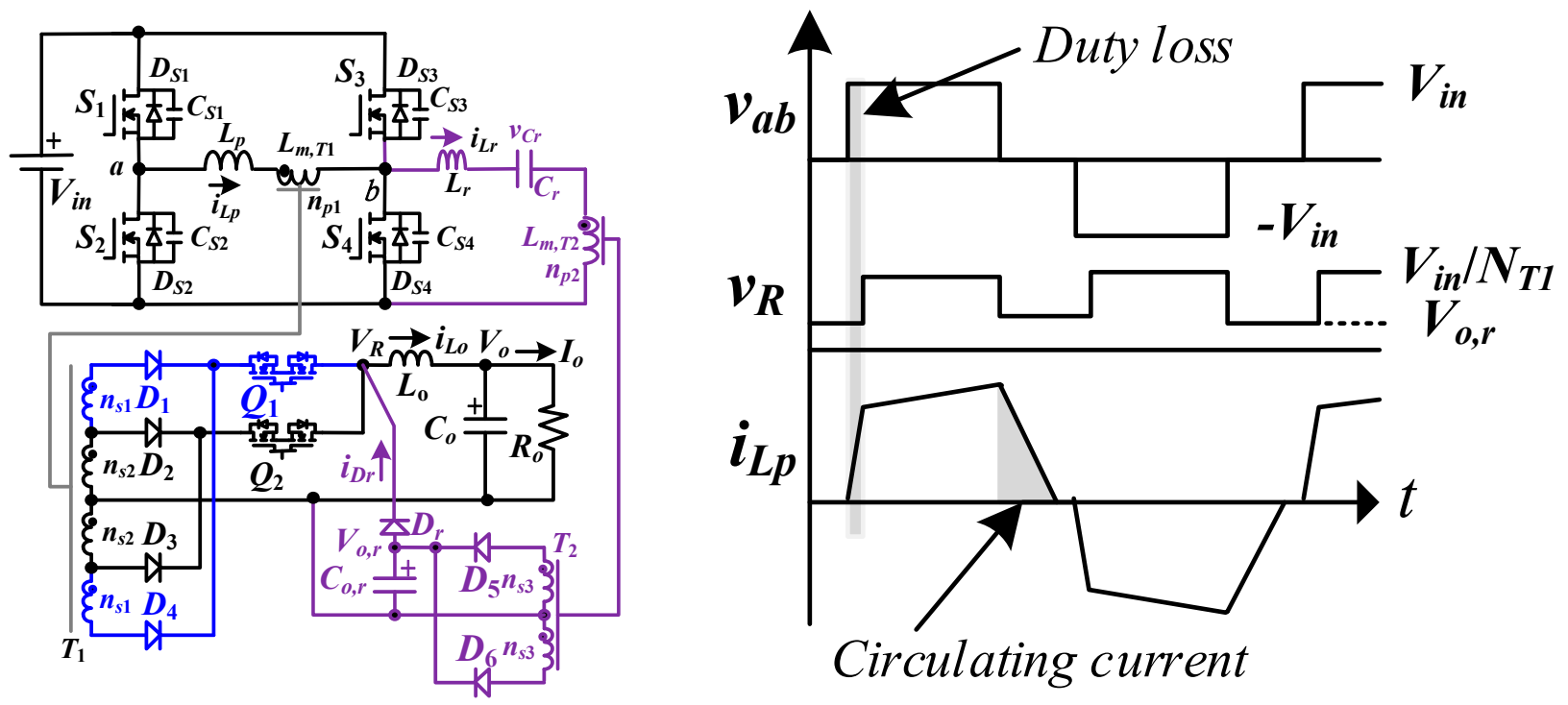

(b)

Figure 1. Circuit diagram (a) conventional phase-shift pulse-width modulation (PSPWM) converter and its pulse-width modulation (PWM) signals (b) presented circuit structure. 

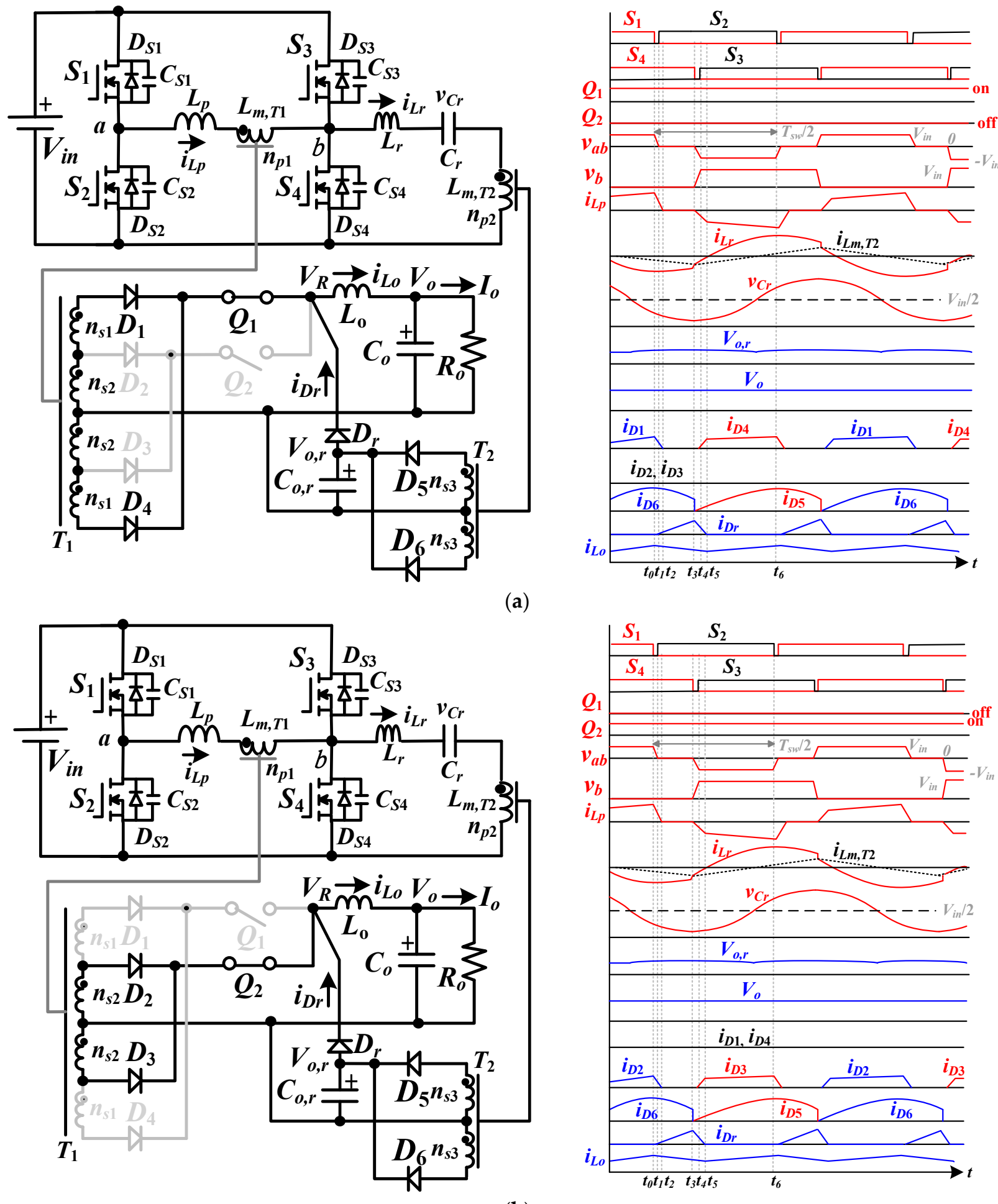

(b)

Figure 2. Equivalent sub-circuits and PWM signals under (a) low input voltage range (b) high input voltage range.

\section{Operation Principle of the Present Circuit}

On the basis of the input voltage range, two cub-circuits can be operated in the present converter. Figure $2 \mathrm{a}$, b provide two sub-circuits under low and high input voltage regions. Under the low voltage region $\left(V_{\text {in, } \min } \sim 2.2 V_{\text {in, min }}\right)$, the full-bridge PWM converter with high secondary turns is operated to obtain high DC voltage gain. To achieve high voltage gain, $Q_{1}$ turns on and $Q_{2}$ turns off. Thus, the transformer turns ratio in Figure 2a becomes 
$N_{T 1}=n_{p 1} /\left(n_{s 1}+n_{s 2}\right)$. Under the high voltage region $\left(2.2 V_{i n, \min } \sim 5 V_{i n, \min }\right)$, the present converter only needs low voltage gain to control load voltage. Therefore, $Q_{1}$ turns off and $Q_{2}$ turns on to have fewer winding turns on the secondary side. The transformer turns ratio in Figure $2 \mathrm{~b}$ becomes $N_{T 1}=n_{p 1} / n_{s 2}$. Due to input voltage deviation, the PSPWM modulation is selected to control active devices and regulate the duty ratio of PWM signals. The resonant circuit is used in the presented circuit in order to improve the ZVS load range for lagging-leg switches. The output voltage $V_{o, r}$ of resonant converter is connected to the rectified terminal voltage $V_{R}$. Ths positive voltage $V_{o, r}$ can decrease the current $i_{L p}$ to 0 at a freewheeling state. Then, the freewheeling current loss is improved. In the adopted circuit, the inductance $L_{R} \ll<L_{m, T 1}$ and the output capacitances of $S_{1} \sim S_{4}$ are $C_{S 1}=C_{S 2}=C_{S 3}=$ $C_{S 4}=C_{\text {oss }}$

For the low voltage input case $\left(V_{i n, \min } \sim 2.2 V_{i n, \min }\right)$, the PWM signals are shown in Figure 2a. In the low input voltage region, $Q_{1}$ turns on and $Q_{2}$ turns off. It is obvious that the fast recovery diodes $D_{2}$ and $D_{3}$ are both reverse biased. In this equivalent operating circuit, the secondary turns of $T_{1}$ are equal to $n_{s 1}+n_{s 2}$. From Figure $2 \mathrm{a}$, six states are operated in every half switching period. The equivalent state circuits for the first half switching period are provided in Figure 3.

State $1\left[t_{0} \sim t_{1}\right.$ ]: At $t_{0}, i_{L P}=i_{L o} / N_{T 1}$ and $i_{D r}=0$. Thus, $D_{r}$ is reverse biased. $S_{1}$ and $S_{4}$ are ON so that $D_{1}$ conducts, the leg voltage $v_{a b}=V_{\text {in }}$ and $v_{L o} \approx V_{\text {in }} / N_{T 1}-V_{o}$. Thus, the primary current $i_{L p}$ and output inductor current $i_{L o}$ are increased and given in Equations (1) and (2).

$$
\begin{gathered}
i_{L p}(t) \approx i_{L p}\left(t_{0}\right)+\left(V_{i n}-N_{T 1} V_{o}\right)\left(t-t_{0}\right) /\left(N_{T 1}^{2} L_{o}\right) \\
i_{L o}(t) \approx N_{T 1} i_{L p}(t)
\end{gathered}
$$

Power transfer between input and output terminals is through a full-bridge PWM converter in this state. The resonant circuit is controlled at the resonant frequency. Since $S_{4}$ is $\mathrm{ON}$, the inductor current $i_{L r}$ will decrease and $i_{L r}$ is less than the magnetizing current $i_{L m, T 2}$. Therefore, $D_{6}$ is forward biased and LLC converter will store energy on $C_{o, r}$.

State $2\left[t_{1} \sim t_{2}\right.$ ]: At $t_{1}, S_{1}$ is off. Prior to $t_{1}, i_{L p}$ is positive. After time $t_{1}, i_{L p}$ will discharge $C_{S 2}$. If the energy $\left(L_{p}+N_{T 1}^{2} L_{o}\right) i_{L p}^{2}\left(t_{1}\right)>2 C_{o s s} V_{i n}^{2}$, then $v_{C S 2}$ will decline to 0 at time $t_{2}$. The discharge time of $C_{S 2}$ is $\Delta t_{12} \approx 2 V_{\text {in }} C_{o s s} N_{T 1} / I_{0}$. To ensure the ZVS operation, the other necessary condition is $t_{d}$ (dead time between $S_{2}$ and $\left.S_{1}\right)>\Delta t_{12}$. LLC circuit is still operated at resonant mode $\left(f_{s w}=f_{r}=1 / 2 \pi \sqrt{L_{r} C_{r}}\right)$.

State $3\left[t_{2} \sim t_{3}\right]: v_{C S 2}=0$ at $t_{2}$. Then $i_{L p}$ flows through $D_{S 2}$ and keeps $v_{C S 2, d s}=0$. Hence, $S_{2}$ can turn on to realize ZVS operation. The secondary rectified voltage $V_{R}$ is decreased to $V_{o, r}$ so that diode $D_{r}$ becomes forward biased and obtains $V_{R}=V_{o, r}$. The primary and secondary inductor voltages $v_{L p}=-N_{T 1} V_{o, r}$ and $v_{L o}=V_{o, r}-V_{o}<0$. It can obtain that $i_{L p}$ and $i_{L o}$ are both decreased in state 3 .

$$
\begin{gathered}
i_{L p}(t) \approx i_{L p}\left(t_{2}\right)-N_{T 1} V_{o, r}\left(t-t_{2}\right) / L_{p} \\
i_{L o}(t) \approx i_{L o}\left(t_{2}\right)+\left(V_{o, r}-V_{o}\right)\left(t-t_{2}\right) / L_{o}
\end{gathered}
$$

In a traditional PSPWM converter, $v_{L p} \approx 0$ and $i_{L p}$ almost constant at the freewheeling state. From (3), $i_{L p}$ in the proposed hybrid converter is decreased in this state. If the freewheeling time interval is large enough, $i_{D 1}$ or $i_{L p}$ can be decreased to zero.

$$
\Delta t_{i_{L P}=0} \approx L_{p} I_{0} /\left(N_{T 1}^{2} V_{o, r}\right)
$$

From Equation (5), one can be observed, the time $\Delta i_{L p=0}$ is dependent on $I_{0}$ and $V_{o, r}$. For full load condition, a more freewheeling time interval is needed to achieve no circulating current advantage. 


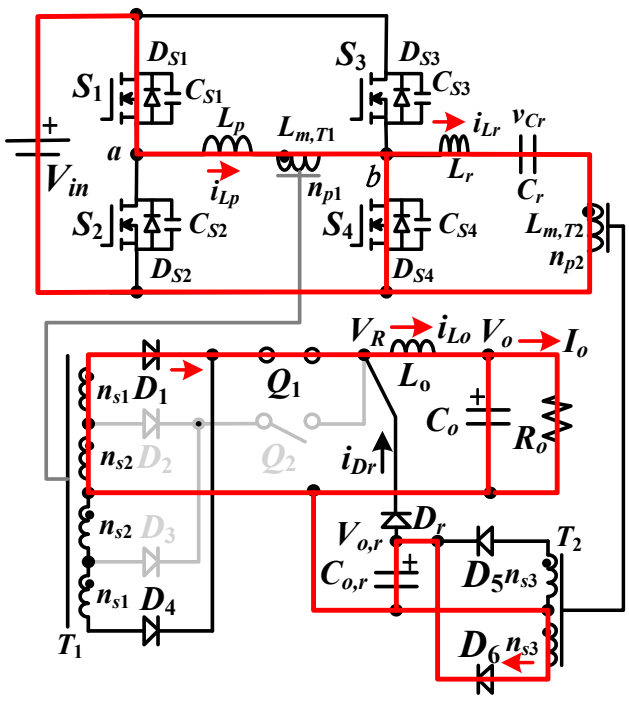

(a)

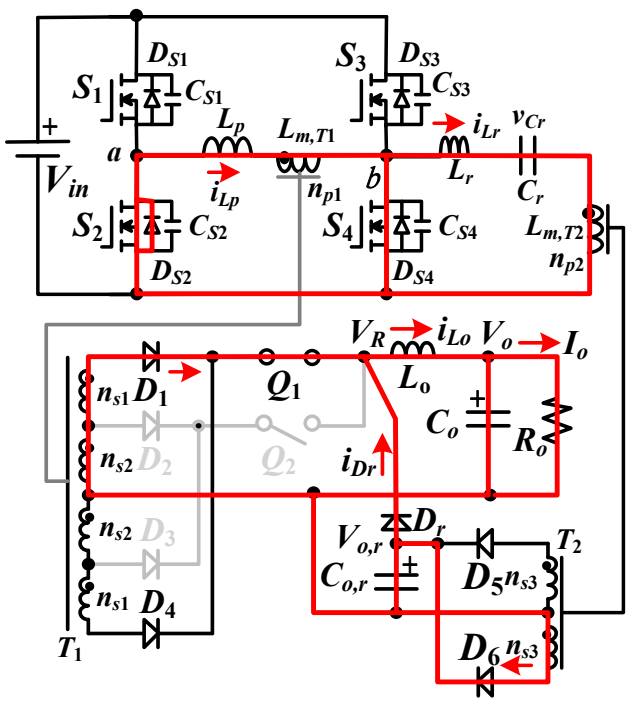

(c)

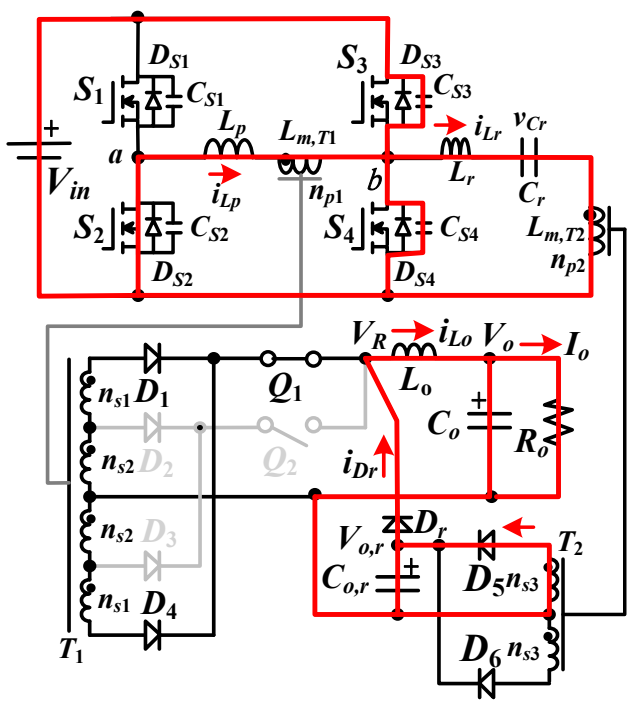

(e)

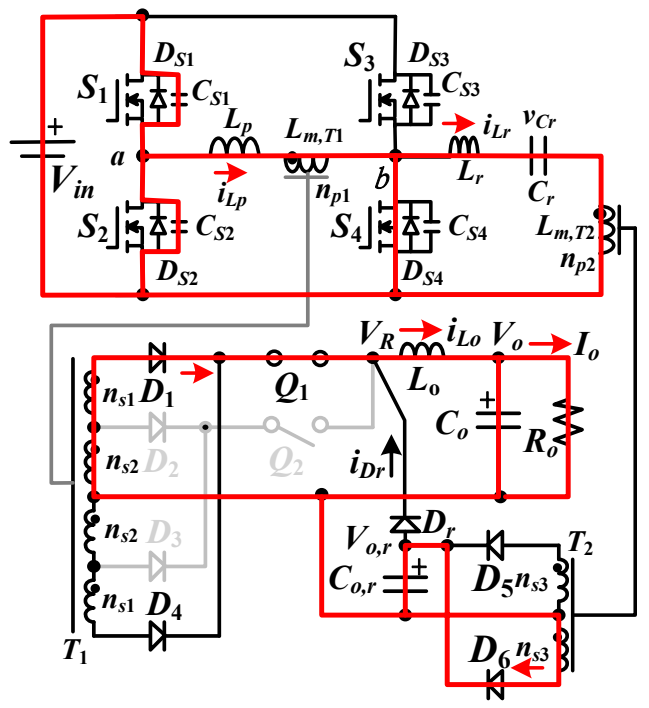

(b)

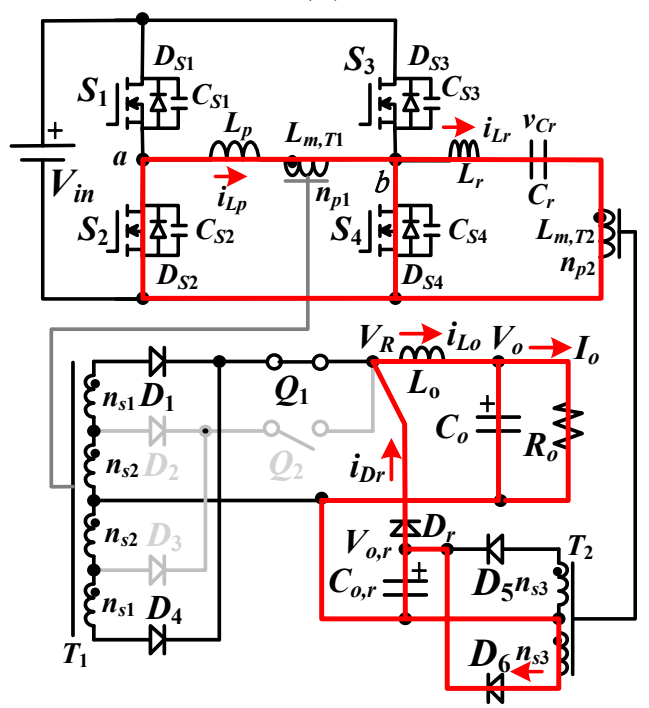

(d)

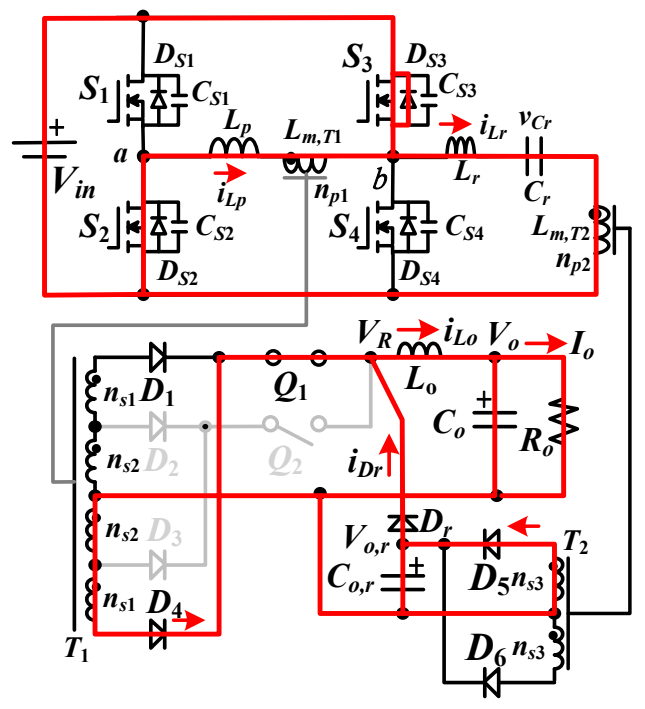

(f)

Figure 3. State circuits of the first half switching cycle under low voltage input operation (a) state 1 circuit (a) state 1 (b) state 2 (c) state 3 (d) state 4 (e) state 5 (f) state 6. 
State $4\left[t_{3} \sim t_{4}\right]$ : At $t_{3}, i_{D 1}=0, i_{L p} \approx 0$ and $i_{D r}=i_{L o}$. Hence, the circulating current is removed at a freewheeling state. In state 4 , power transfer is from $V_{\text {in }}$ to $V_{o}$ through $L L C$ circuit, $D_{r}$ and $L_{o}$. The filter inductor voltage $v_{L o}=V_{o, r}-V_{o}<0$ and $i_{L o}$ is decreased in this state.

State $5\left[t_{4} \sim t_{5}\right]$ : At time $t_{4}, S_{4}$ turns off. Prior to $t_{4}, i_{L r}-i_{L p}<0 . C_{S 3}$ is discharged when $S_{4}$ is turned off. Diode $D_{5}$ becomes forward biased in $L L C$ circuit. Owing to $L L C$ operation, $v_{C S 3}$ can be easily decreased to 0 and $S_{3}$ can turn on at zero voltage at time $t_{5}$.

State $6\left[t_{5} \sim t_{6}\right]$ : At time $t_{5}, C_{S 3}$ is discharged to zero voltage. $D_{S 3}$ becomes forward biased and $S_{3}$ can turn on at zero voltage switching after time $t_{5}$. The leg voltage $v_{a b}=-V_{\text {in }}$ and $D_{4}$ become forward biased. Since $i_{D 4}<i_{L o}, D_{r}$ is conducting. The inductor voltage $v_{L p}$ $\approx N_{T 1} V_{o, r}-V_{\text {in }}<0$ and $i_{L p}$ decreases. At time $t_{6}$, the diode current $i_{D 4}=i_{L o}, i_{L p}=-i_{L o} / N_{T 1}$ and $i_{D r}=0$. The time interval of state 6 is expressed as $\Delta t_{56} \approx I_{0} L_{p} /\left[N_{T 1}\left(V_{i n}-N_{T 1} V_{o, r}\right)\right]$. Since $D_{r}$ is conducting in this state, the duty ratio loss of PSPWM circuit at state 6 is calculated as $d_{6} \approx f_{s w} I_{o} L_{p} /\left[N_{T 1}\left(V_{i n}-N_{T 1} V_{o, r}\right)\right]$. The current $i_{L o}$ is still decreased in state 6 . This state is ended at time $t_{6}$.

The proposed circuit can also be operated at high voltage input conditions $\left(2.2 V_{\text {in, } \min } \sim\right.$ $\left.5 V_{\text {in }, \text { min }}\right)$. The PWM waveforms for high voltage input operation are provided in Figure $2 b$. Under high voltage input, $Q_{1}$ is controlled at OFF state and $Q_{2}$ is ON. Due to $Q_{1}$ is OFF, $D_{1}$ and $D_{4}$ become OFF. The full-bridge PWM converter has turns ratio $N_{T 1}=n_{p 1} / n_{s 2}$. Since the switching frequency of $L L C$ circuit is equal to the resonant frequency, active devices $S_{3}$ and $S_{4}$ are turned on at ZVS operation. Due to $D_{r}$ is connecting $V_{o, r}$ and $V_{R}$, the primary current $i_{L p}$ can be decreased to 0 at the freewheeling state. Figure 4 provides the state circuits for first half switching period under high voltage input operation.

State $1\left[t_{0} \sim t_{1}\right.$ ]: $i_{L P}$ is increased and equal to $i_{L o} / N_{T 1}$ at time $t_{0}$. Thus, $D_{r}$ becomes reverse biased. The leg voltage $v_{a b}=V_{i n}$ and $D_{2}$ is forward biased. The currents $i_{L p}$ and $i_{L o}$ are increased. Power flow from $V_{\text {in }}$ to $V_{o}$ is finished by a full-bridge converter. Due to $i_{L r}<$ $i_{L m, T 2}, D_{6}$ is forward biased in state 1 .

State $2\left[t_{1} \sim t_{2}\right.$ ]: At $t_{1}, S_{1}$ is turned off and $i_{L p}\left(t_{1}\right)>0 . i_{L p}$ discharge capacitor $C_{S 2}$. If $\left(L_{p}+N_{T 1}^{2} L_{o}\right) i_{L p}^{2}\left(t_{1}\right)>2 C_{o s s} V_{i n}^{2}$, then $v_{C S 2}$ will decrease to zero at time $t_{2}$. LLC converter is controlled at resonant mode, $v_{\mathrm{Cr}}$ is decreased and $D_{6}$ is conducting.

State $3\left[t_{2} \sim t_{3}\right]$ : At $t_{2}, v_{C S 2}=0$ and $D_{S 2}$ is forward biased due to $i_{L p}>0$. Active device $S_{2}$ turns on at ZVS and leg voltage $v_{a b}=0$. The secondary voltage $V_{R}$ is clamped at $V_{o, r}$ due to $D_{r}$ is forward biased. It can obtain $v_{L p}=-N_{T 1} V_{o, r}$ and $v_{L o}=V_{o, r}-V_{o}<0$. Both $i_{L p}$ and $i_{L o}$ are decreased in this state.

State 4 [ $\left.t_{3} \sim t_{4}\right]:$ At $t_{3}, i_{D 2}$ is decreased to 0 and $i_{D r}=i_{L o}$. Hence, diode $D_{2}$ is reverse biased. $L L C$ converter will transfer power from $V_{\text {in }}$ to $V_{o}$ through $D_{r}$ and $L_{o}$. The inductor voltage $v_{L o}=V_{o, r}-V_{o}<0$ and $i_{L o}$ is decreased in state 4 .

State $5\left[t_{4} \sim t_{5}\right]: S_{4}$ turns off at time $t_{4}$. Since $i_{L r}\left(t_{4}\right)-i_{L p}\left(t_{4}\right)<0, v_{C S 3}$ is decreased after time $t_{4}$. Due to $i_{L r}>i_{L m, T 2}, D_{5}$ becomes forward biased. $L L C$ circuit is operated at inductive load so that $v_{C S 3}$ can be easily decreased to 0 .

State $6\left[t_{5} \sim t_{6}\right]$ : At $t_{5}, v_{C S 3}=0$. Then, $D_{S 3}$ is on so that $S_{3}$ can turn on at this moment to achieve soft switching operation. In state $6, v_{a b}=-V_{i n}$ and $D_{3}$ is ON. Since $D_{r}$ is still conducting, it can obtain $v_{L p} \approx N_{T 1} V_{o, r}-V_{\text {in }}<0$ and $i_{L p}$ is decreased. At time $t_{6}, i_{D 4}=i_{L o}$ and $D_{r}$ becomes reverse biased. The primary current $i_{L p}=-i_{L o} / N_{T 1}$. Since $v_{L o}=V_{o, r}-V_{o}<0$, $i_{\text {Lo }}$ is decreased. State 6 ends at time $t_{6}$. 


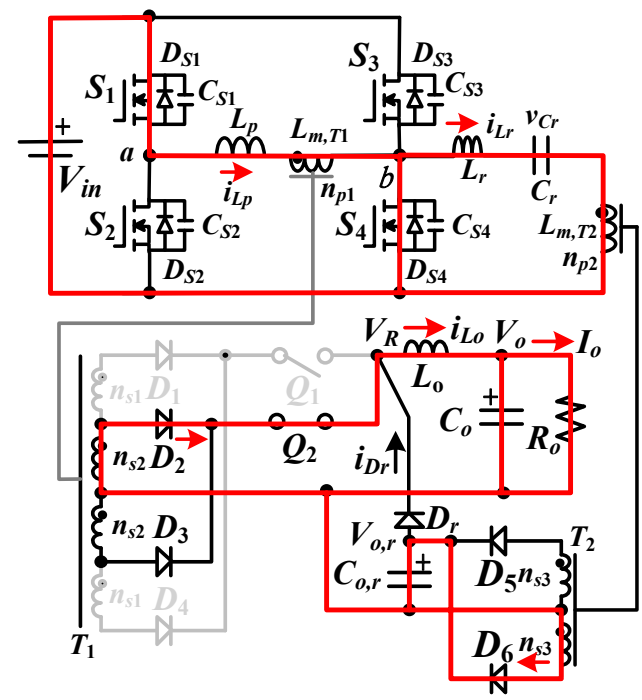

(a)

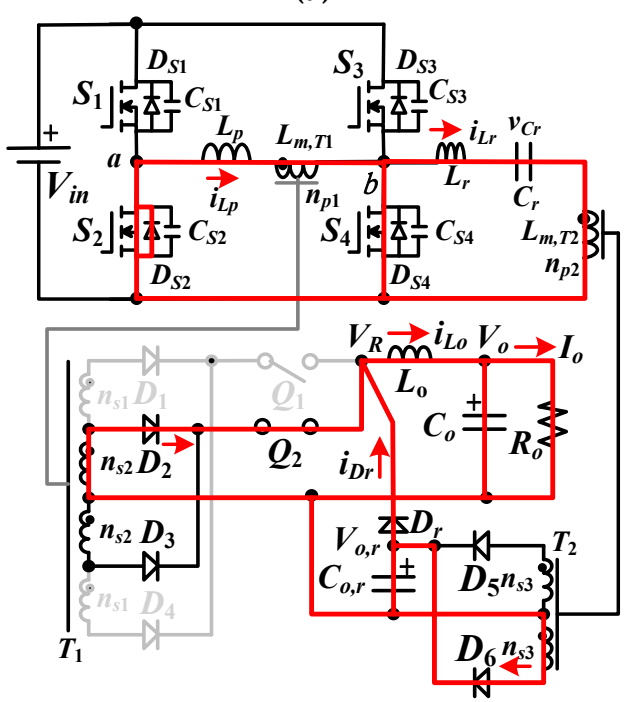

(c)

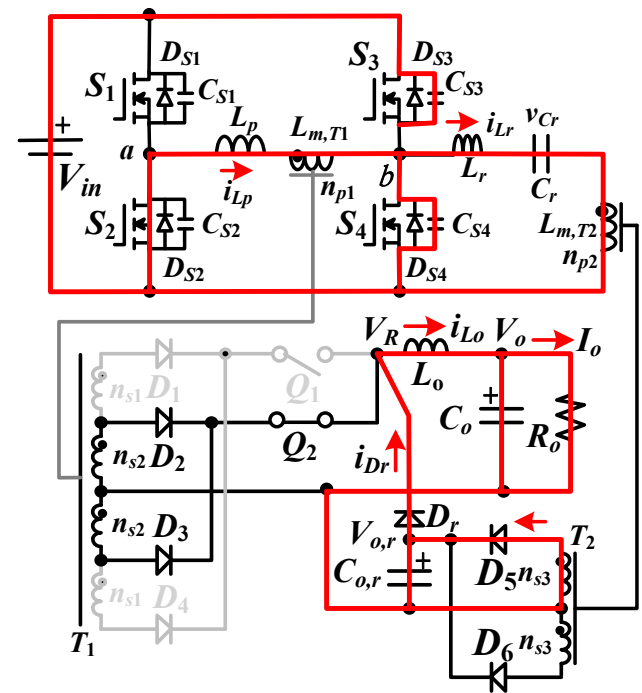

(e)

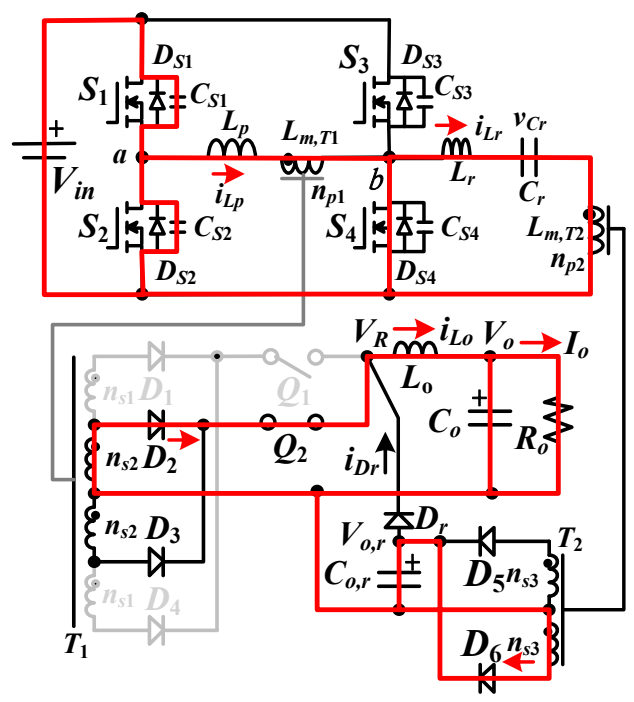

(b)

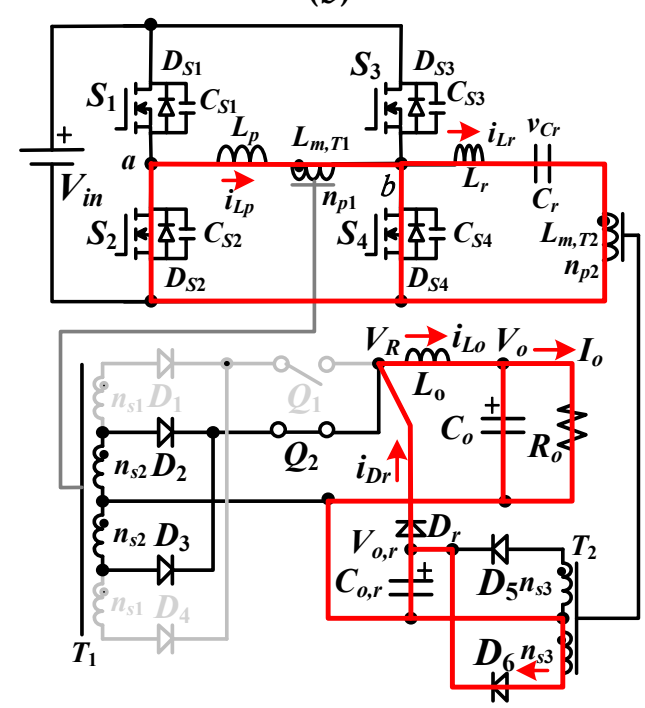

(d)

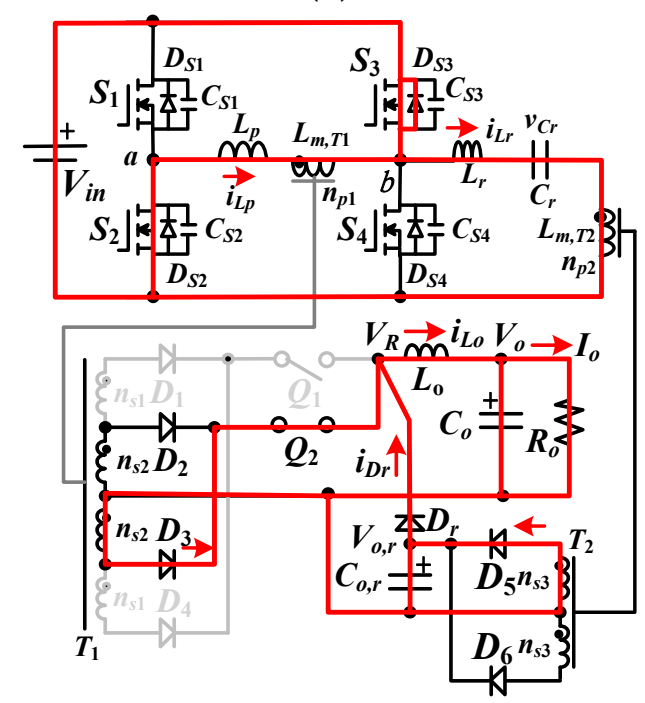

(f)

Figure 4. State circuits of the first half switching cycle under high voltage input operation (a) state 1 circuit (a) state 1 (b) state 2 (c) state 3 (d) state 4 (e) state 5 (f) state 6. 


\section{Circuit Analysis of the Presented Converter}

The advantages of the studied hybrid PSPWM circuit are a wide load range of soft switching, less circulating current and wide input voltage operation. The hard switching drawback and high freewheeling current problem of conventional PSPWM converter are overcome by using an $L L C$ converter in the proposed circuit. Since the switching frequency of $L L C$ circuit is equal to the resonant frequency, active switches of the PSPWM converter can be turned on at ZVS. To realize a wide input voltage deviation problem, four winding sets and two switches are adopted on the low voltage side to control DC voltage gain. Under low input voltage conditions, the winding turns $n_{S 1}+n_{S 2}$ are selected on the secondary side. Under a high input voltage case, the $n_{S 2}$ turns are used on the output side. In the presented circuit, the resonant circuit is controlled under constant switching frequency (equal series resonant frequency). Hence, $V_{o, r}$ is approximately equal to $V_{\text {in }} /\left(2 N_{\mathrm{T} 2}\right)=V_{\text {in }} n_{S 3} /\left(2 n_{p 2}\right)$. In the presented phase-shift PWM converter, there is a duty loss in state 6 . The inductor voltage $v_{L o}$ in states 1 and 2 is equal tp $V_{i n} / N_{T 1}-V_{o}$. However, $v_{L o}$ in states 3-6 is equal to $V_{o, r}-V_{o}=V_{\text {in }} /\left(2 N_{\mathrm{T} 2}\right)-V_{o}$. Apply the voltage-second balance to $L_{o}$, the voltage $V_{o}$ is derived as.

$$
V_{o} \approx\left[d_{e}\left(1-\frac{N_{T 1}}{2 N_{T 2}}\right)+\frac{N_{T 1}}{4 N_{T 2}}\right] \frac{2 V_{i n}}{N_{T 1}}
$$

where $d_{e}=d-d_{6}$ is the effective duty cycle and $N_{T 1}=n_{p 1} /\left(n_{s 1}+n_{s 2}\right)$ or $n_{p 1} / n_{s 2}$ for low or high voltage input condition, respectively. In a traditional PSPWM converter, the output voltage is expressed in Equation (7).

$$
V_{o, \text { con }}=\frac{2 d_{e} V_{i n}}{N_{T 1}}
$$

Comparing Equations (6) and (7), it obtains $G_{d c}=N_{T 1} V_{o} /\left(2 V_{i n}\right)>G_{d c, c o n}=$ $N_{T 1} V_{o, \text { con }} /\left(2 V_{\text {in }}\right)$. That means the presented circuit has larger DC gain than the traditional PSPWM converter. Due to the full-bridge circuit structure, $S_{1} \sim S_{4}$ has $V_{i n, \max }$ voltage stress. The switches $Q_{1}$ and $Q_{2}$ have voltage stress $V_{i n} n_{s 1} / n_{p 1}$. The voltage stresses on the fast recovery diodes $D_{1} \sim D_{6}$ and $D_{r}$ are obtained in Equations (8)-(11).

$$
\begin{gathered}
V_{D 1, \text { rating }}=V_{D 4, \text { rating }}=2 V_{i n}\left(n_{s 1}+n_{s 2}\right) / n_{p 1} \\
V_{D 2, \text { rating }}=V_{D 3, \text { rating }}=2 V_{i n} n_{s 2} / n_{p 1} \\
V_{D 5, \text { rating }}=V_{D 6, \text { rating }}=V_{i n} n_{s 3} / n_{p 2} \\
V_{D r, \text { rating }}=V_{i n} / N_{T 1}-V_{i n} /\left(2 N_{T 2}\right)
\end{gathered}
$$

The dc diode currents of $D_{1} \sim D_{6}$ and $D_{r}$ are $I_{D 1}=I_{D 2}=I_{D 3}=I_{D 4 v} \approx d_{e} I_{0}$, $I_{D 5}=I_{D 6} \approx\left(0.5-d_{e}\right) I_{o}$ and $I_{D r} \approx\left(1-2 d_{e}\right) I_{0}$. The inductor voltage $v_{L o}=V_{i n} / N_{T 1}-$ $V_{o}$ in states 1 and 2 and $v_{L o}=V_{o, r}-V_{o}$ in states $3 \sim 6$. Therefore, $L_{o}$ in conventional fullbridge PWM converter and the proposed hybrid converter are expressed in Equations (12) and (13).

$$
\begin{gathered}
L_{o, \text { con }}>V_{o}\left(0.5-d_{e}\right) /\left(f_{s w} \Delta i_{L o}\right) \\
L_{o}>\left(V_{o}-\frac{V_{i n}}{2 N_{T 2}}\right)\left(0.5-d_{e}\right) /\left(f_{s w} \Delta i_{L o}\right)
\end{gathered}
$$

Comparison of Equations (12) and (13), it is clear that the presented hybrid PWM circuit has less output inductance $L_{0}$. The output power of the resonant circuit is $P_{L L C} \approx(0.5-$ $\left.d_{e f f}\right) I_{o} V_{i n} / N_{T 2}$ and the output power of the PSPWM circuit is $P_{P W M}$ circuit $\approx 2 d_{e} I_{o} V_{i n} / N_{T 1}$.

\section{Experimental Results}

The presented hybrid PSPWM circuit is investigated and confirmed by a prototype circuit. The rated power of the proposed circuit is $P_{0, \max }=800 \mathrm{~W}$, the input and output 
voltages are $V_{\text {in }}=90 \mathrm{~V}-450 \mathrm{~V}$ and $V_{o}=48 \mathrm{~V}$. The switching frequency is $f_{s w}=70 \mathrm{kHz}$. In the presented circuit, $Q_{1}$ and $Q_{2}$ are $\mathrm{ON}$ and OFF under $90 \mathrm{~V} \leq V_{\text {in }}<200 \mathrm{~V}$ (low voltage input). Therefore, the transformer $T_{1}$ has turns ratio $N_{T 1}=n_{p 1} /\left(n_{s 1}+n_{s 2}\right)$. On the other hand, $Q_{1}$ and $Q_{2}$ are $\mathrm{OFF}$ and $\mathrm{ON}$ under $200 \mathrm{~V}<V_{\text {in }} \leq 450 \mathrm{~V}$ (high voltage input). Transformer $T_{1}$ has turns ratio $N_{T 1}=n_{p 1} / n_{s 2}$. To present signal oscillation at $V_{\text {in }}=200 \mathrm{~V}$, a Schmitt comparator with $\pm 10 \mathrm{~V}$ tolerance is adopted in the control circuit to control $Q_{1}$ and $Q_{2}$. Hence, $Q_{1}$ is $\mathrm{ON}$ and $Q_{2}$ is OFF at $90 \mathrm{~V} \leq V_{\text {in }} \leq 210 \mathrm{~V}$, and $Q_{1}$ is OFF and $Q_{2}$ is $\mathrm{ON}$ at $190 \mathrm{~V} \leq V_{\text {in }} \leq$ $450 \mathrm{~V}$ in the control algorithm. The general purpose PWM integrated circuit UCC3895 is selected to control $S_{1}-S_{4}$. The switches $Q_{1}$ and $Q_{2}$ are controlled by a voltage comparator. The component parameters of the laboratory prototype circuit are provided in Table 1. Figure 5 a gives the picture of the prototype circuit. The control blocks of the presented converter are given in Figure 5b. The output voltage controller is based on the type III voltage control algorithm [18]. The output of the voltage controller is to regulate the phase shift angle between the leading-leg switches and lagging-leg switches. The gate drivers are used to turn on or off the switching devices $S_{1}-S_{4}$. In order to realize the wide input voltage operation, a Schmitt trigger comparator with $200 \mathrm{~V}$ reference voltage is adopted to select the low $\left(Q_{1} \mathrm{ON}\right.$, if $\left.V_{\text {in }}<200 \mathrm{~V}\right)$ or high $\left(Q_{2} \mathrm{ON}\right.$, if $\left.V_{\text {in }}>200 \mathrm{~V}\right)$ input voltage region. The measured waveforms of the proposed circuit for $V_{\text {in }}=90 \mathrm{~V}$ and $210 \mathrm{~V}$ under the low voltage region are illustrated in Figures 6 and 7. Similarly, Figures 8 and 9 provide the experimental waveforms under $V_{i n}=190 \mathrm{~V}$ and $450 \mathrm{~V}$ at high voltage regions. The primary-side signals $\left(v_{S 1, g}, v_{S 4, g}, v_{a b}\right.$, and $\left.i_{L p}\right)$ of the full-bridge converter under $V_{\text {in }}=90 \mathrm{~V}$, $210 \mathrm{~V}, 190 \mathrm{~V}$ and $450 \mathrm{~V}$ are illustrated in Figures 6a, 7a, 8a and 9a, respectively. One can observe that the proposed converter has a less effective duty ratio at $V_{\text {in }}=210 \mathrm{~V}(450 \mathrm{~V})$ than $V_{i n}=90 \mathrm{~V}(190 \mathrm{~V})$. The circulating current of $i_{L p}$ at the freewheeling state $\left(v_{a b}=0\right)$ can be improved and reduced to zero at $V_{\text {in }}=210 \mathrm{~V}, 190 \mathrm{~V}$ and $450 \mathrm{~V}$ in Figures 7a, 8a and 9a. The primary-side waveforms $\left(v_{S 3, g}, v_{S 4, g}, v_{C r}\right.$, and $\left.i_{L r}\right)$ of the resonant converter at $V_{\text {in }}=90,210,190$ and $450 \mathrm{~V}$ are provided in Figures $6 \mathrm{~b}, 7 \mathrm{~b}, 8 \mathrm{~b}$ and $9 \mathrm{~b}$, respectively. The resonant capacitor voltage $v_{C r}$ contains a dc voltage value that is equal to $V_{\text {in }} / 2$. Figures $6 \mathrm{c}$ and $7 \mathrm{c}$ provide the measured output side waveforms of PSPWM converter at $V_{\text {in }}=90 \mathrm{~V}$ and $210 \mathrm{~V}$. For the low voltage input region, $Q_{1}$ is ON and $Q_{2}$ is OFF. Therefore, $D_{2}$ and $D_{3}$ are reverse biased. At the freewheeling state $\left(v_{a b}=0\right), D_{r}$ is conducting to clamp $V_{R}=V_{o, r}$ and force $V_{L o}=V_{o, r}-V_{o}<0$. Therefore, $i_{L o}$ is decreased at this freewheeling state. Similarly, Figures $8 \mathrm{c}$ and $9 \mathrm{c}$ provide the measured waveforms of $i_{D 2}, i_{D 3}, i_{D \mathrm{r}}$ and $V_{o, r 2}$ at $V_{\text {in }}=190 \mathrm{~V}$ and $450 \mathrm{~V}$ under the high voltage region. The measured secondary-side waveforms of the resonant converter at $V_{\text {in }}=90,210,190$ and $450 \mathrm{~V}$ are illustrated in Figures $6 \mathrm{~d}, 7 \mathrm{~d}, 8 \mathrm{~d}$ and $9 \mathrm{~d}$, respectively. Figure 10 demonstrates the test results of $S_{1}$ (at leading-leg) and $S_{4}$ (at lagging-leg) at $V_{\text {in }}=90 \mathrm{~V}$ input for $20 \%$ load and full load conditions. Owing to the energy on $L_{\mathrm{o}}$ is adopted to discharge the leading-leg switch $S_{1}$, one can observe that switch $S_{1}$ in Figure 10a,b have ZVS turn-on operation. Due to the LLC circuit operation, $S_{4}$ can achieve ZVS turn-on operation shown in Figure 10 c,d at $20 \%$ and $100 \%$ power conditions. Similarly, the measured waveforms of $S_{1}$ (at leading-leg) and $S_{4}$ (at lagging-leg) at $V_{\text {in }}=190 \mathrm{~V}, 210 \mathrm{~V}$ and $450 \mathrm{~V}$ under 20\% load and full load are demonstrated in Figures 11-13, respectively. Due to the phase-shift PWM operation of the DC full-bridge converter, the PWM signals of $S_{2}$ and $S_{3}$ have the same operation characteristics as $S_{1}$ and $S_{4}$. From the experimental results in Figures 10-13, it is clear that all switches have ZVS characteristic from $20 \%$ load to full load for all input voltage range. Figure 14 provides the relationship between the signals of $Q_{1}$ and $Q_{2}$ and input voltage $V_{i n}$. When $V_{\text {in }}>90 \mathrm{~V}$ and $<210 \mathrm{~V}$ (in low voltage input range), $Q_{1}$ turns on and $Q_{2}$ turns off. The $n_{1}+n_{2}$ turns are selected to achieve high voltage gain. On the other hand, $Q_{1}$ turns off and $Q_{2}$ turns on, if $V_{\text {in }}>210 \mathrm{~V}$ (in high voltage input range). The $n_{2}$ turns are selected to reduce voltage gain. If the input voltage $V_{\text {in }}$ is declined from $450 \mathrm{~V}$ and $V_{\text {in }}<190 \mathrm{~V}$, then $Q_{1}$ will turn on and $Q_{2}$ turns off. The measured efficiencies of the prototype circuit are about $90 \%, 88 \%, 92 \%$ and $89 \%$ at $V_{\text {in }}=90 \mathrm{~V}, 210 \mathrm{~V}$, $190 \mathrm{~V}$ and $450 \mathrm{~V}$, respectively, under full load conditions. 
Table 1. Circuit parameters in the laboratory prototype.

\begin{tabular}{cccc}
\hline Items. & Parameter & Items & Parameter \\
\hline$V_{\text {in }}$ & $90 \sim 450 \mathrm{~V}$ & $V_{o}$ & $48 \mathrm{~V}$ \\
\hline$L_{o}$ & $32 \mu \mathrm{H}$ & $S_{1} \sim S_{4}, Q_{1}, Q_{2}$ & STF40N60M2 \\
\hline$P_{o}$ & $800 \mathrm{~W}$ & $D_{1} \sim D_{4}$ & MSC015SDA120B \\
\hline$f_{s w}$ & $70 \mathrm{kHz}$ & $D_{5}, D_{6}$ & STPS 30M80CFP \\
\hline$L_{p}$ & $8 \mu \mathrm{H}$ & $D_{r}$ & SBR60A300CT \\
\hline$L_{r}$ & $13 \mu \mathrm{H}$ & $n_{p 1}: n_{s 1}: n_{s 2}$ & $17: 7: 7$ \\
\hline$C_{r}$ & $410 \mathrm{nF}$ & $n_{p 2}: n_{s 3}$ & $19: 2$ \\
\hline$C_{o, r}$ & $330 \mu \mathrm{F} / 100 \mathrm{~V}$ & $L_{m, T 2}$ & $66 \mu \mathrm{H}$ \\
\hline$C_{o}$ & $12800 \mu \mathrm{F} / 100 \mathrm{~V}$ & & \\
\hline
\end{tabular}

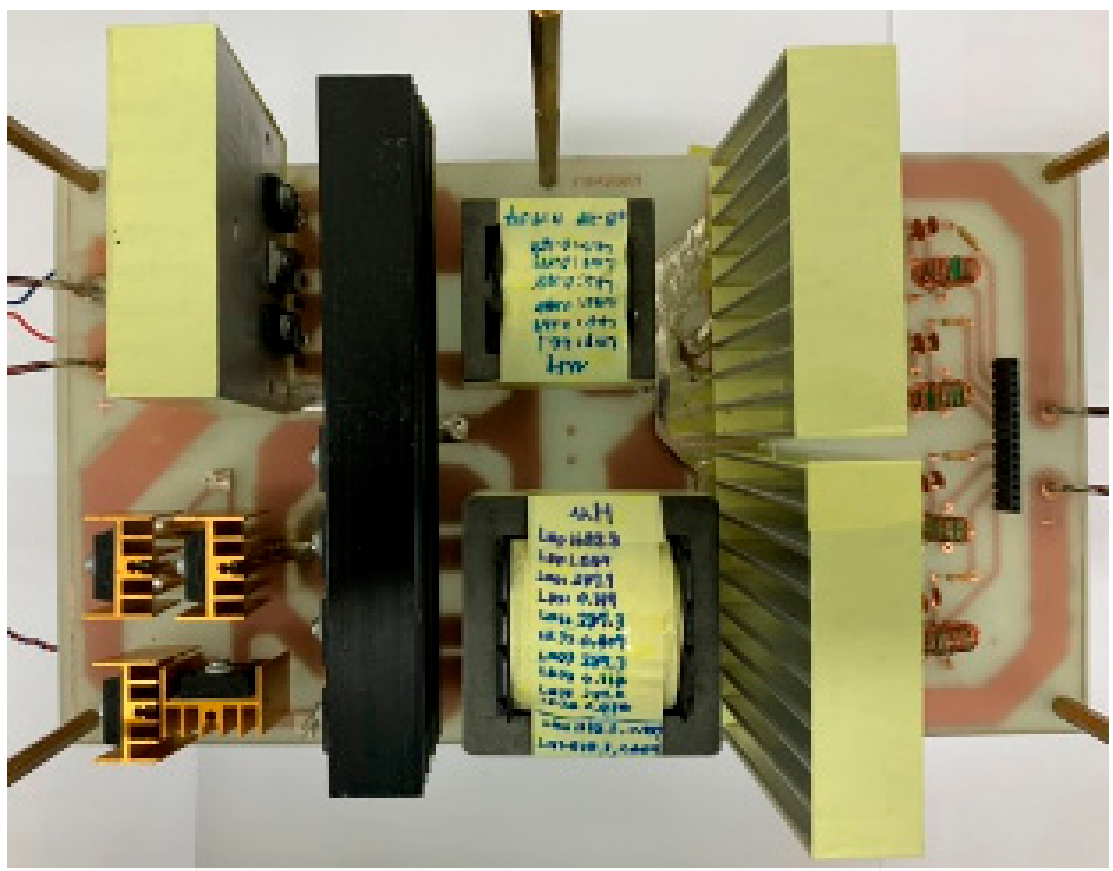

(a)

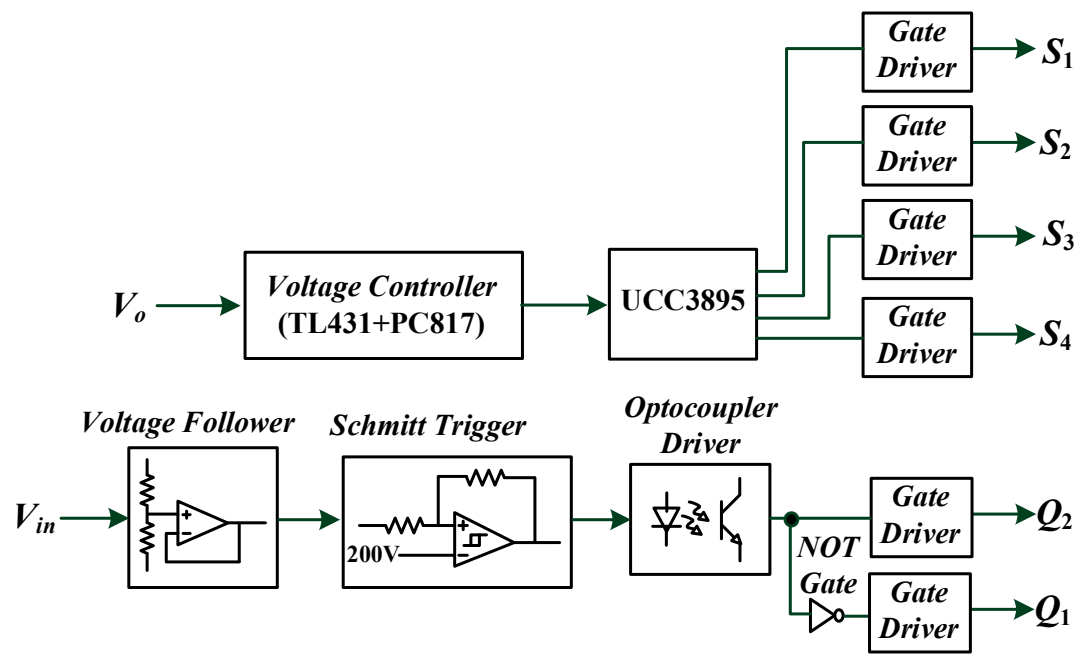

(b)

Figure 5. Prototype circuit (a) picture of the proposed converter (b) control blocks. 


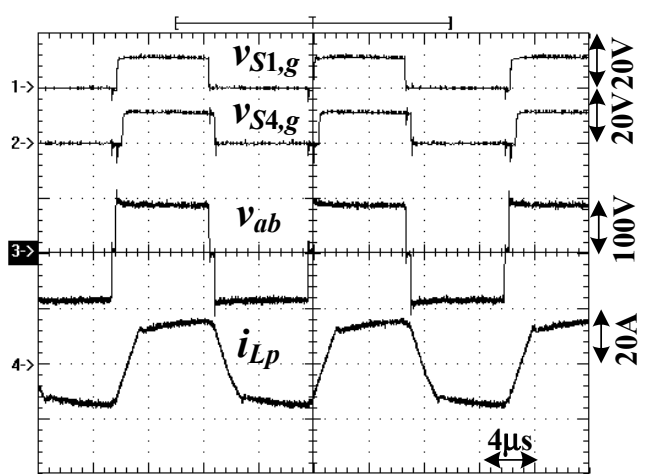

(a)

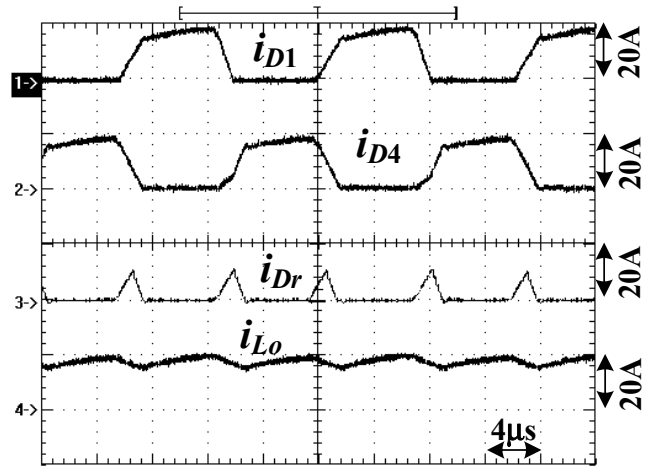

(c)

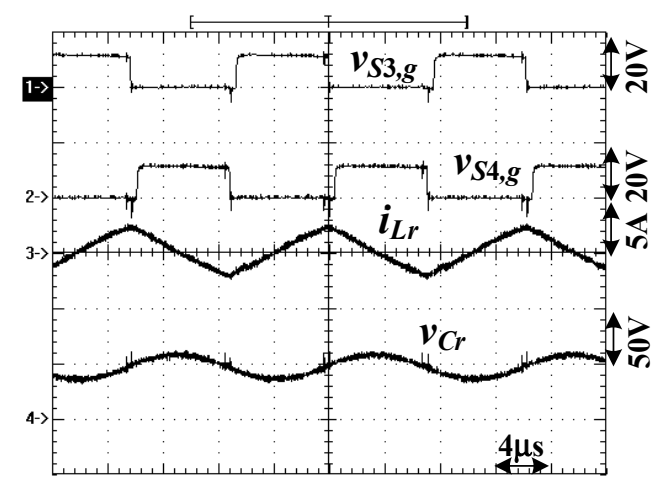

(b)

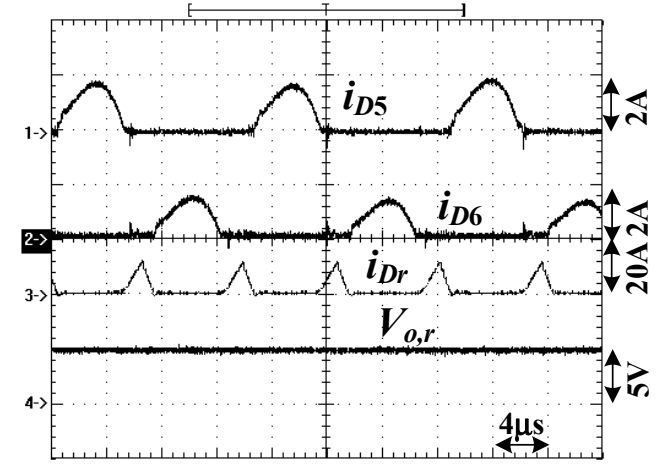

(d)

Figure 6. Experimental results at $V_{\text {in }}=90 \mathrm{~V}$ and full load under low voltage input region (a) $v_{S 1, g}$, $v_{S 4, g}, v_{a b}$, and $i_{L p}(\mathbf{b}) v_{S 3, g}, v_{S 4, g}, v_{C r}$, and $i_{L r}(\mathbf{c}) i_{D 1}, i_{D 4}, i_{D r}$, and $i_{L o}(\mathbf{d}) i_{D 5}, i_{D 6}, i_{D r}$, and $V_{o, r}$.

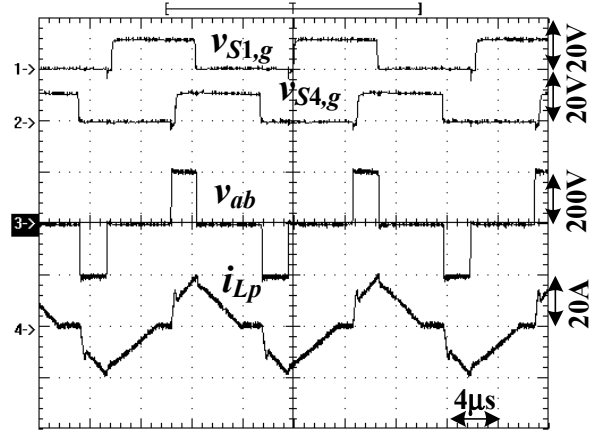

(a)

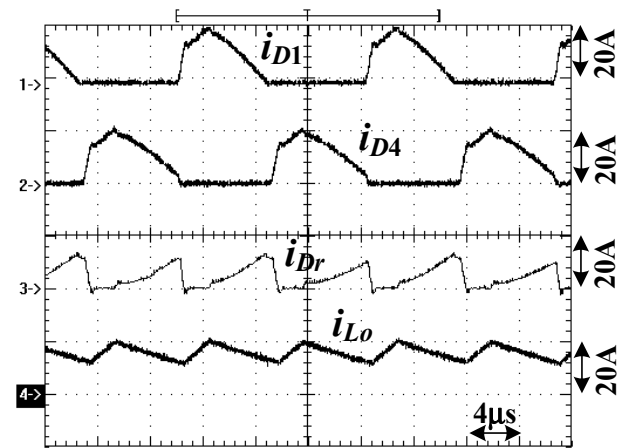

(c)

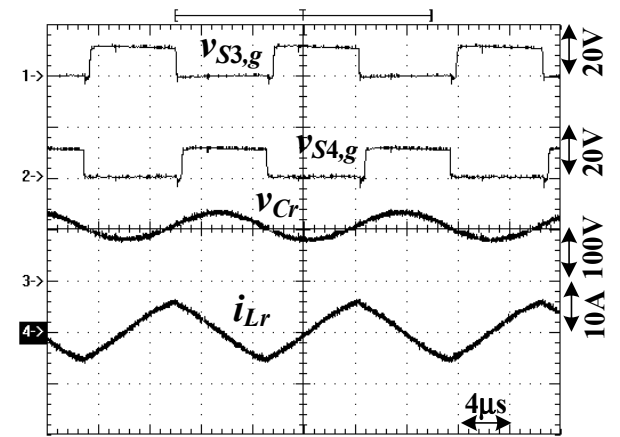

(b)

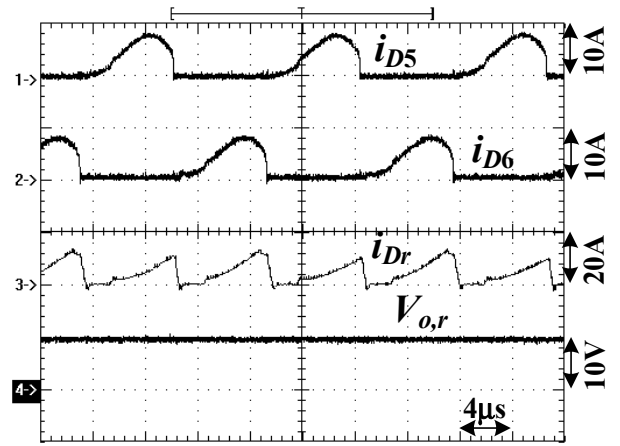

(d)

Figure 7. Measured results at $V_{i n}=210 \mathrm{~V}$ and full load under low voltage input region $(\mathbf{a}) v_{S 1, g}, v_{S 4, g}$, $v_{a b}$, and $i_{L p}(\mathbf{b}) v_{S 3, g}, v_{S 4, g}, v_{C r}$, and $i_{L r}(\mathbf{c}) i_{D 1}, i_{D 4}, i_{D r}$, and $i_{L o}(\mathbf{d}) i_{D 5}, i_{D 6}, i_{D r}$, and $V_{o, r}$. 


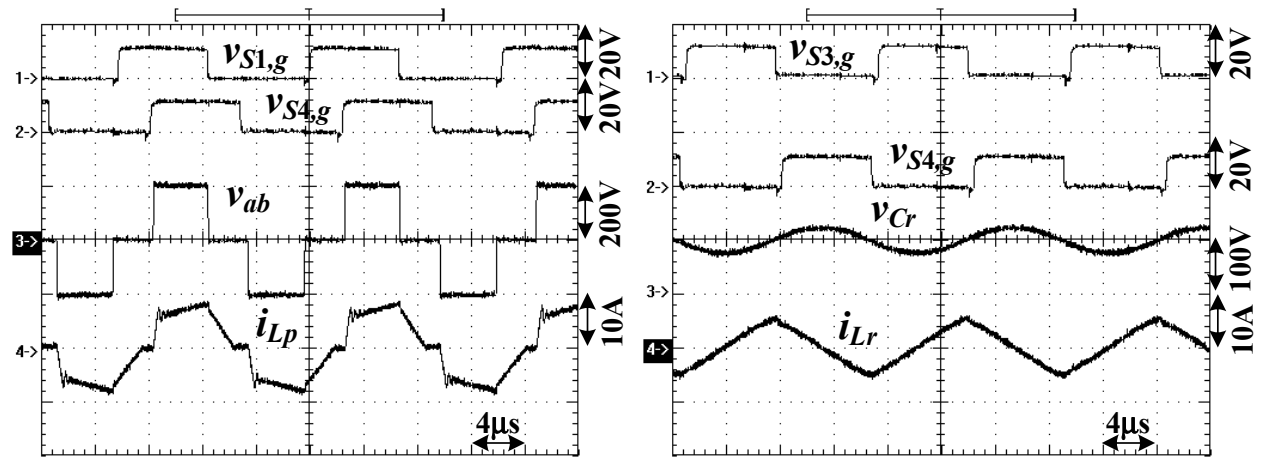

(a)

(b)

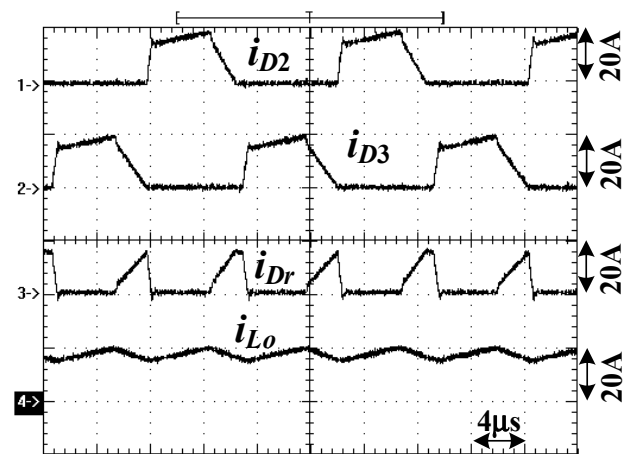

(c)

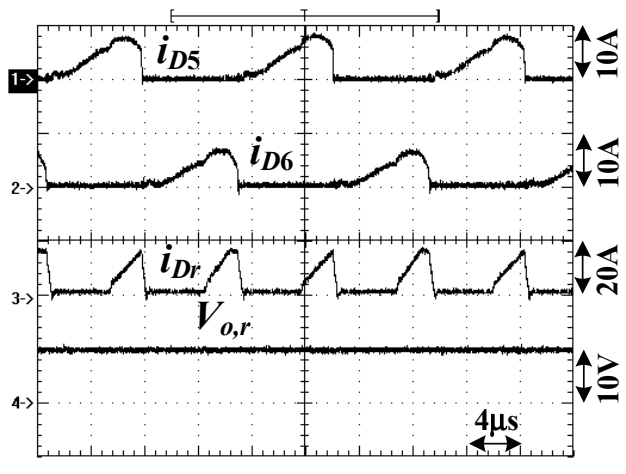

(d)

Figure 8. Measured results at $V_{\text {in }}=190 \mathrm{~V}$ and full load under high voltage input region (a) $v_{S 1, g}$, $v_{S 4, g}, v_{a b}$, and $i_{L p}(\mathbf{b}) v_{S 3, g}, v_{S 4, g}, v_{C r}$, and $i_{L r}(\mathbf{c}) i_{D 2}, i_{D 3}, i_{D r}$, and $i_{L o}(\mathbf{d}) i_{D 5}, i_{D 6}, i_{D r}$, and $V_{o, r}$.

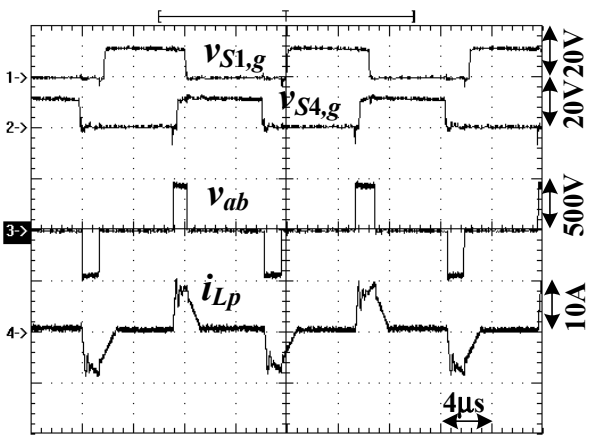

(a)

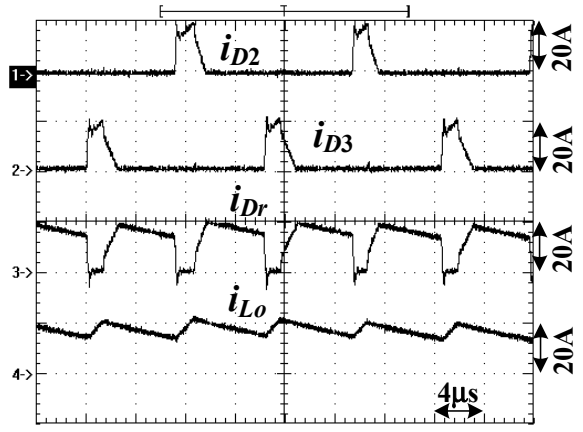

(c)

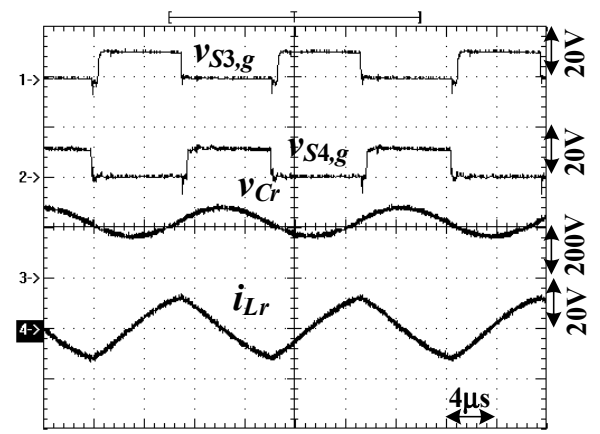

(b)

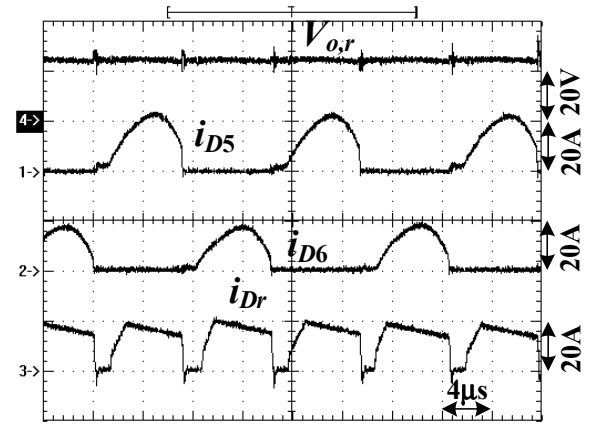

(d)

Figure 9. Measured results at $V_{\text {in }}=450 \mathrm{~V}$ and full load under high voltage input region (a) $v_{S 1, g}$, $v_{S 4, g}, v_{a b}$, and $i_{L p}(\mathbf{b}) v_{S 3, g}, v_{S 4, g}, v_{C r}$, and $i_{L r}(\mathbf{c}) i_{D 2}, i_{D 3}, i_{D r}$, and $i_{L o}(\mathbf{d}) i_{D 5}, i_{D 6}, i_{D r}$, and $V_{o, r}$. 


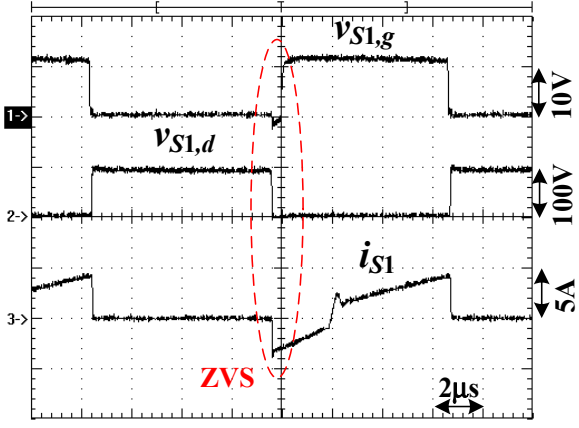

(a)

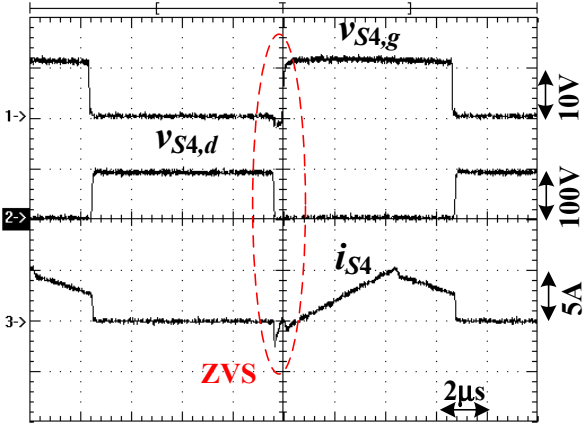

(c)

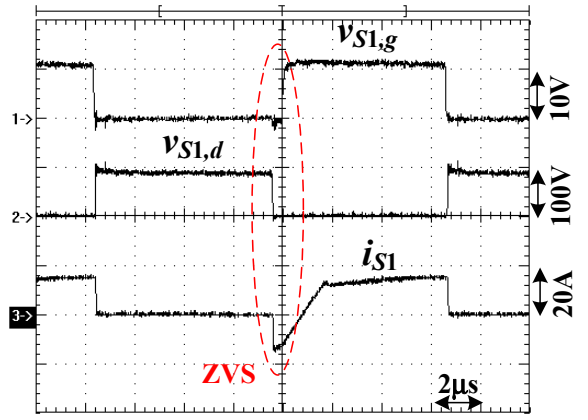

(b)

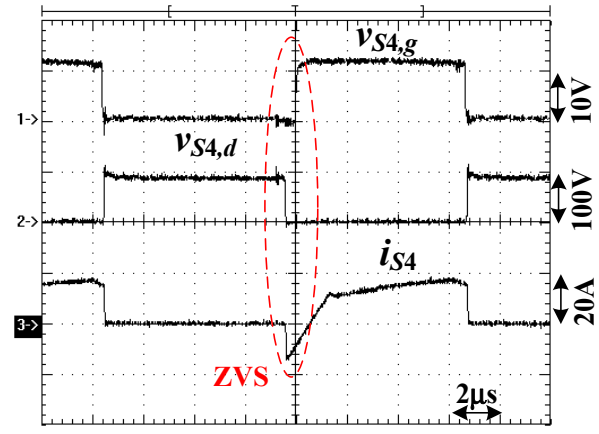

(d)

Figure 10. Measured results of $S_{1}$ and $S_{4}$ at $V_{\text {in }}=90 \mathrm{~V}$ input (a) $S_{1}$ waveforms at $160 \mathrm{~W}$ (20\% load) (b) Scheme 1. waveforms at $800 \mathrm{~W}$ (full load) (c) $S_{4}$ waveforms at $160 \mathrm{~W}$ (20\% load) (d) $S_{4}$ waveforms at $800 \mathrm{~W}$ (full load).

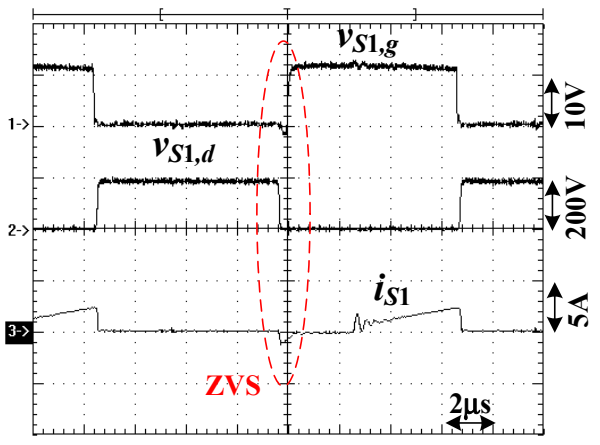

(a)

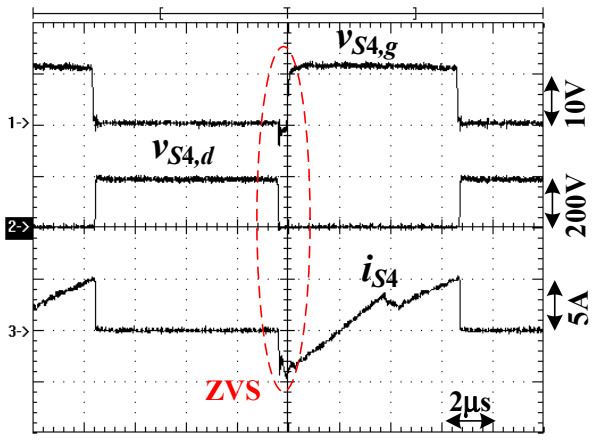

(c)

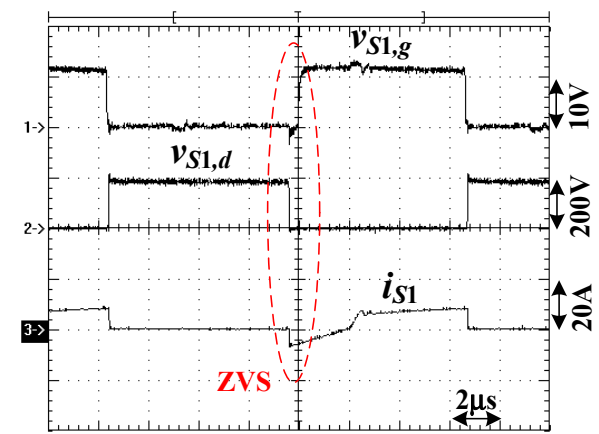

(b)

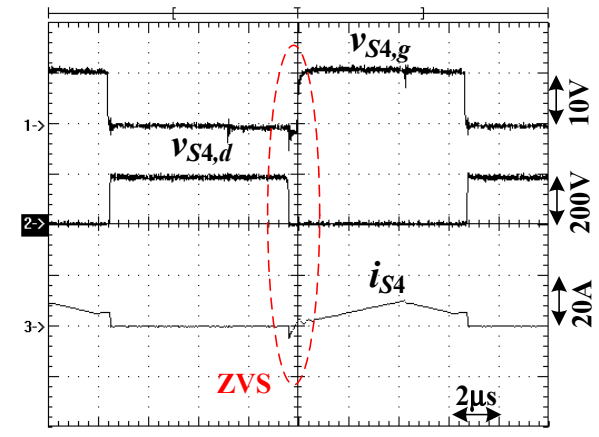

(d)

Figure 11. Measured results of $S_{1}$ and $S_{4}$ at $V_{\text {in }}=190 \mathrm{~V}$ input (a) $S_{1}$ waveforms at $160 \mathrm{~W}$ (20\% load) (b) Scheme 1. waveforms at $800 \mathrm{~W}$ (full load) (c) $S_{4}$ waveforms at $160 \mathrm{~W}$ (20\% load) (d) $S_{4}$ waveforms at $800 \mathrm{~W}$ (full load). 


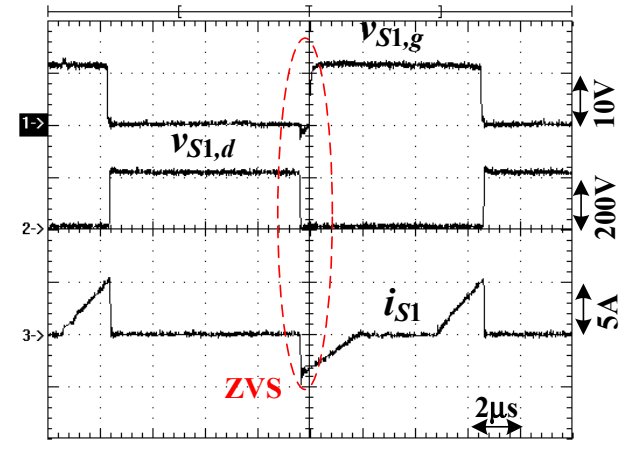

(a)

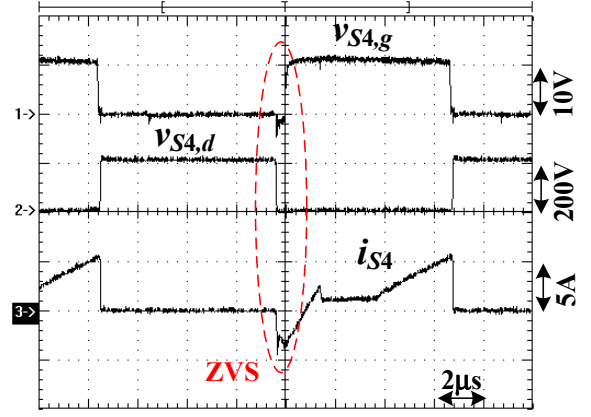

(c)

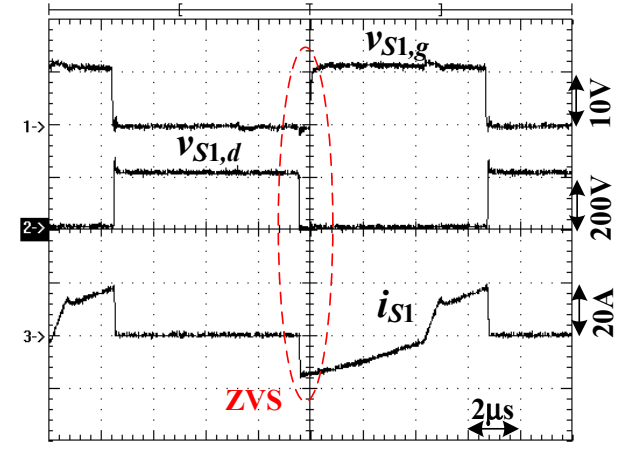

(b)

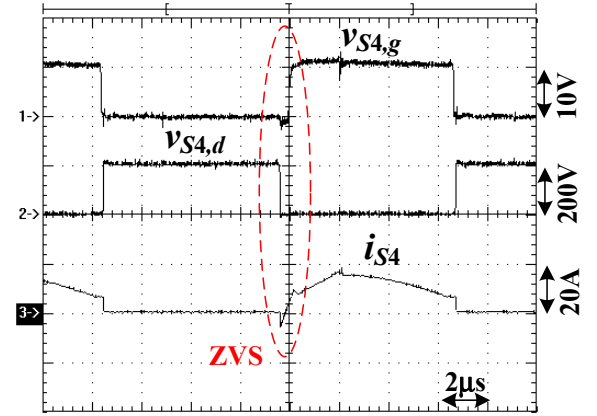

(d)

Figure 12. Measured results of $S_{1}$ and $S_{4}$ at $V_{\text {in }}=210 \mathrm{~V}$ input (a) $S_{1}$ waveforms at $160 \mathrm{~W}$ (20\% load) (b) Scheme 1. waveforms at $800 \mathrm{~W}$ (full load) (c) $S_{4}$ waveforms at $160 \mathrm{~W}$ (20\% load) (d) $S_{4}$ waveforms at $800 \mathrm{~W}$ (full load).

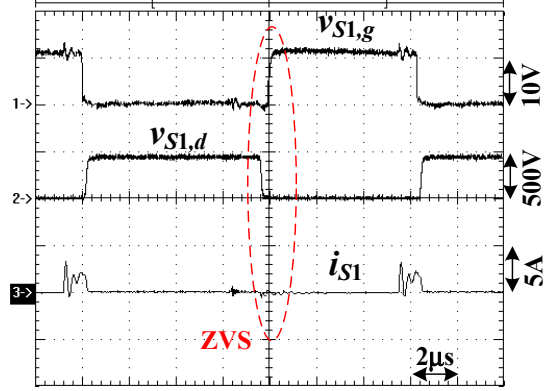

(a)

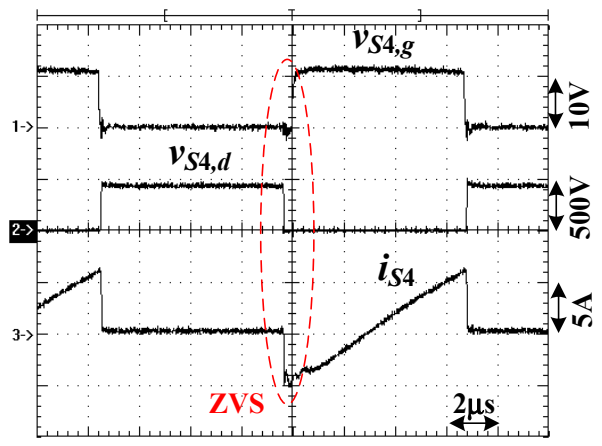

(c)

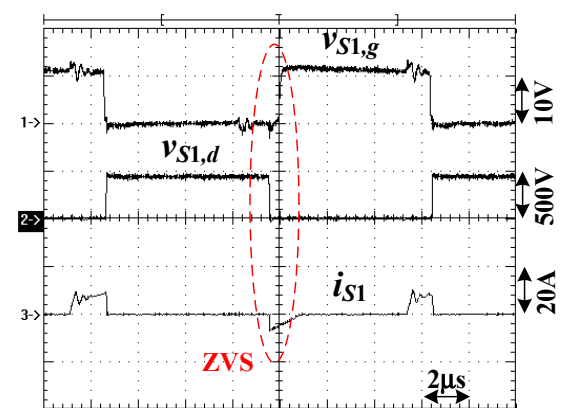

(b)

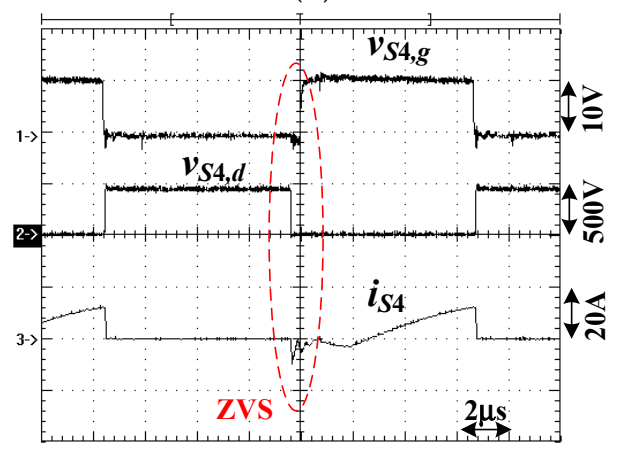

(d)

Figure 13. Measured results of $S_{1}$ and $S_{4}$ at $V_{\text {in }}=450 \mathrm{~V}$ input (a) $S_{1}$ waveforms at $160 \mathrm{~W}$ (20\% load) (b) Scheme 1. waveforms at $800 \mathrm{~W}$ (full load) (c) $S_{4}$ waveforms at $160 \mathrm{~W}$ (20\% load) (d) $S_{4}$ waveforms at $800 \mathrm{~W}$ (full load). 


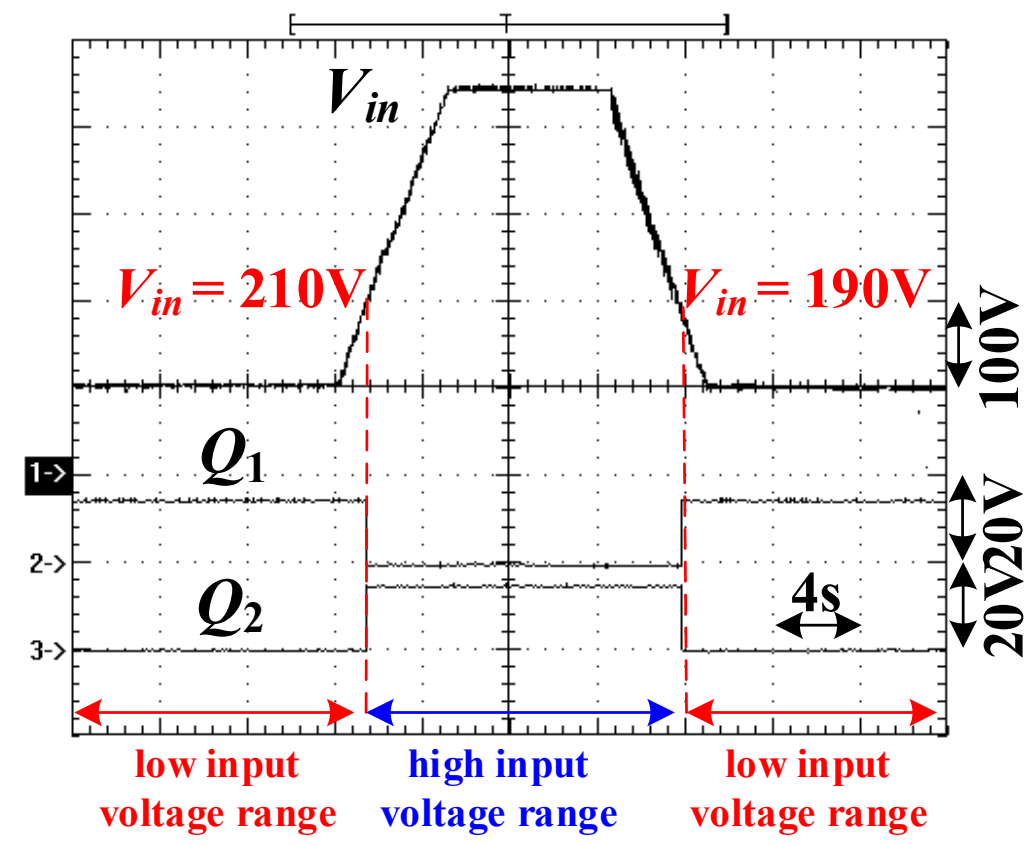

Figure 14. Measured waveforms of input voltage and PWM signals of $Q_{1}$ and $Q_{2}$ under $100 \%$ load.

\section{Conclusions}

A hybrid PWM converter is discussed and implemented to improve the drawbacks of the traditional PSPWM converter. The advantages of the presented circuit are low primary current stress at the freewheeling state, low switching losses at the lagging-leg switches and more wide input voltage operation for PV power renewable energy applications. Compare to the conventional PWM converters in [10-17] with wide input voltage or output voltage operation, the proposed circuit has fewer power switches on the primary side. The LLC resonant converter is used on the lagging-leg of the conventional PSPWM converter to reduce the switching loss. Thus, the switching losses on the proposed converter are improved. The high freewheeling current loss of conventional phase-shift PWM converter is also improved by the connection of the output DC voltage of the resonant circuit to the rectified terminal of the PSPWM circuit. However, the proposed converter has more circuit components compared to the other wide input voltage PWM converters. The performance of the presented hybrid PWM circuit is provided from the experiments with an $800 \mathrm{~W}$ prototype circuit. Further work will consider reducing the active or passive components in the presented converter, decreasing the circuit cost and maintaining the same converter performance.

Author Contributions: Conceptualization, methodology, investigation, visualization, writingoriginal draft, writing-review and editing, B.-R.L.; validation, Y.-K.L. All authors have read and agreed to the published version of the manuscript.

Funding: This research is funded by the Ministry of Science and Technology (MOST), Taiwan, under grant number MOST 108-2221-E-224-022-MY2.

Institutional Review Board Statement: Not applicable.

Informed Consent Statement: Not applicable.

Data Availability Statement: Not applicable.

Acknowledgments: The authors are grateful to the financial support by the Ministry of Science and Technology (MOST), Taiwan.

Conflicts of Interest: The authors declare no conflict of interest. 


\section{References}

1. Zhang, Y.; Fu, C.; Sumner, M.; Wang, P. A Wide Input-Voltage Range Quasi-Z-source Boost DC-DC Converter with High-Voltage Gain for Fuel Cell Vehicles. IEEE Trans. Ind. Electron. 2018, 65, 5201-5212. [CrossRef]

2. Wang, P.; Zhou, L.; Zhang, Y.; Li, J.; Sumner, M. Input-Parallel Output-Series DC-DC Boost Converter with a Wide Input Voltage Range, for Fuel Cell Vehicles. IEEE Trans. Vehicular Tech. 2017, 66, 7771-7781. [CrossRef]

3. Wang, H.; Nayar, C.; Su, J.; Ding, M. Control and Interfacing of a Grid-Connected Small-Scale Wind Turbine Generator. IEEE Trans. Energy Convers. 2011, 26, 428-434. [CrossRef]

4. Xia, Y.Y.; Fletcher, J.E.; Finney, S.J.; Ahmed, K.H.; Williams, B.W. Torque Ripple Analysis and Reduction for Wind Energy Conversion Systems Using Uncontrolled Rectifier and Boost Converter. IET Renew. Power Gener. 2011, 5, 377-386. [CrossRef]

5. Teodorescu, R.; Liserre, M.; Rodriguez, P. Grid Converters for Photovoltaic and Wind Power Systems; John Wiley \& Sons: Hoboken, NJ, USA, 2011.

6. Acharya, A.B.; Ricco, M.; Sera, D.; Reoderscu, R.; Norum, L.E. Performance Analysis of Medium-Voltage Grid Integration of PV Plant Using Modular Multilevel Converter. IEEE Trans. Energy Convers. 2019, 34, 1731-1740. [CrossRef]

7. Bragard, M.; Soltau, N.; Thomas, S.; De Doncker, R.W. The Balance of Renewable Sources and User Demands in Grids: Power Electronics for Modular Battery Energy Storage Systems. IEEE Trans. Power Electron. 2010, 25, 3049-3056. [CrossRef]

8. Chiang, S.; Chang, K.; Yen, C. Residential Photovoltaic Energy Storage System. IEEE Trans. Ind. Electron. 1998, 45, 385-394. [CrossRef]

9. Vega-Garita, V.; Ramirez-Elizondo, L.; Mouli, G.R.C.; Bauer, P. Review of Residential PV-Storage Architectures. In Proceedings of the 2016 IEEE International Energy Conference (ENERGYCON), Leuven, Belgium, 4-8 April 2016; pp. 1-6.

10. Lu, J.; Kumar, A.; Afridi, K.K. Step-Down Impedance Control Network Resonant DC-DC Converter Utilizing an Enhanced Phase-Shift Control for Wide-Input-Range Operation. IEEE Trans. Ind. Appl. 2013, 54, 4523-4536. [CrossRef]

11. Wang, X.; Tian, F.; Batarseh, I. High Efficiency Parallel Post Regulator for Wide Range Input DC-DC Converter. IEEE Trans. Power Electron. 2008, 23, 852-858. [CrossRef]

12. Li, W.; Zong, S.; Liu, F.; Yang, H.; He, X.; Wu, B. Secondary-Side Phase-Shift-Controlled ZVS DC/DC Converter with Wide Voltage Gain for High Input Voltage Applications. IEEE Trans. Power Electron. 2013, 28, 5128-5139. [CrossRef]

13. Jeong, Y.; Kim, J.K.; Lee, J.B.; Moon, G.W. An Asymmetric Half-Bridge Resonant Converter Having a Reduced Conduction Loss for DC/DC Power Applications with a Wide Range of Low Input Voltage. IEEE Trans. Power Electron. 2017, 32, 7795-7804. [CrossRef]

14. Kim, B.; Kim, S.; Hun, D.Y.; Choi, J.H.; Kim, M. Hybrid Resonant Half-Bridge DC/DC Converter with Wide Input Voltage Range. In Proceedings of the IEEE APEC Conference, San Antonio, TX, USA, 4-8 March 2018; pp. 1876-1881.

15. Sun, W.; Xing, Y.; Wu, H.; Ding, J. Modified High-Efficiency LLC Converters with Two Split Resonant Branches for Wide Input-Voltage Range Applications. IEEE Trans. Power Electron. 2018, 33, 7867-7879. [CrossRef]

16. Hu, H.; Fang, X.; Chen, F.; Shen, Z.J.; Batarseh, I. A modified high-efficiency LLC Converter with Two Transformers for Wide Input-Voltage Range Applications. IEEE Trans. Power Electron. 2012, 28, 1946-1960. [CrossRef]

17. Lin, B.R. Implementation of a Parallel-Series Resonant Converter with Wide Input Voltage Range. Energies 2019, $12,4095$. [CrossRef]

18. Basso, C.P. Switching-Mode Power Supplies: Spice Simulations and Practical Designs, 2nd ed.; McGraw Hill Professional: New York, NY, USA, 2014. 